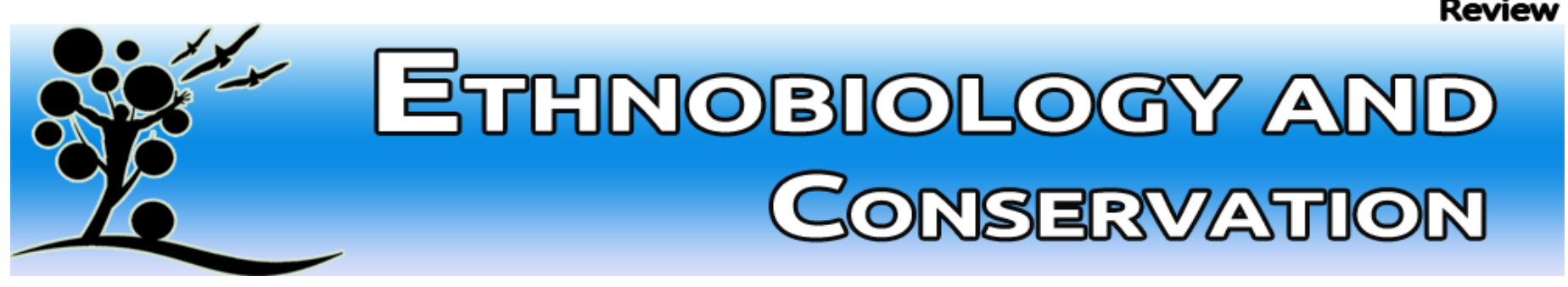

\title{
Is Non-Timber Forest Product Harvest Sustainable in the Less Developed World? A Systematic Review of the Recent Economic and Ecological Literature
}

\begin{abstract}
Denise Stanley ${ }^{1}$, Robert Voeks ${ }^{2^{*}}$, Leaa Short ${ }^{2}$
${ }^{1}$ Department of Economics, MCBE, California State University, Fullerton $800 \mathrm{~N}$. State College Blvd. Fullerton, CA 92834

${ }^{2 *}$ Department of Geography HSS, California State University, Fullerton 800 N. State College Blvd. Fullerton, CA 92834

${ }^{*}$ Corresponding author

$\triangle$ E-mail addresses: DS (dstanley@fullerton.edu), RV $\quad$ (rvoeks@fullerton.edu), LS (leaashort@csu.fullerton.edu)

Ethnobiology and Conservation 2012, 1:9 (11 October 2012)

ISSN 2238-4782

doi: $10.15451 /$ ec2012-8-1.9-1-39

ethnobioconservation.com

Abstract

Non-timber forest products (NTFPs) provide material subsistence and cash income to millions of rural people, particularly in less developed countries. This paper offers a systematic review of recent trends (2000-2010) in the ecological and economic sustainability of NTFPs. Of 101 NTFP ecological studies, most addressed harvest consequences at the population-individual level $(62.4 \%)$, and over half $(52.5 \%)$ were carried out in Latin America. Nearly two-thirds of research $(63.3 \%)$ reported that extraction was sustainable or likely to be so, compared to less than one-fifth $(17.8 \%)$ that found it to be unsustainable. Extractive enterprise in Latin America was most often reported as ecologically sustainable (82.6\%), and least often in Asia (58.8\%). Because little of the economic NTFP literature identifies whether extractive returns meet the financial needs of extractors, at least on a daily basis, we outline economic sustainability criteria in terms of whether returns surpass an absolute poverty line or alternative wage. Of the 71 articles presenting financial data, over two-thirds met or exceeded the threshold of economic sustainability. Roughly $75 \%$ of studies demonstrated that gatherers earned more than USD\$2 PPP/day (the international absolute poverty line) or more than a local wage. These positive results do not, however, demonstrate that gathering reduces long-term poverty because forest dependence, and likely tenure security, remains low among these populations. Caution must be exercised in terms of extending these results into the future, as changing economic conditions, rates and sources of habitat modification, and climate change all point to increased extractive pressures on tropical forests and savannas.
\end{abstract}

Keywords: Non-timber forest product - Non-wood forest product - Extraction - Ethnobotany Ecological sustainability - Economic sustainability 


\section{Introduction}

The extraction of non-timber forest products (NTFPs) from old- and second-growth habitats includes foods, fiber, medicines, latex, and sundry other plant and fungal products (Shackleton et al. 2011; Voeks 2011). Long regarded as economically atavistic and environmentally destructive by government planners, NTFP collection and trade by the 1990s began to be viewed by national and international entities as a potential rural development-resource conservation win-win (Hagen and Fight 1999; Peters et al. 1989; Schwartzman et al. 2000). Whether destined for personal consumptive or commercial ends, NTFPs can open several routes to livelihood improvement among marginalized, rural communities in the developing world (Avocevou-Ayiso et al. 2009). And unlike alternative destructive forms of land use, such as logging, mining and plantation agriculture, the collection of wild nuts and fruits, leaves, bark, resin, and roots affects the structure and function of forests much less than other uses. Under favorable circumstances, NTFP extraction is capable of achieving the overarching goal of sustainable development, that is, "meeting the needs of the present without compromising the ability of future generations to meet their own needs" (UN 1997).

But some have argued that external demand for NTFPs necessarily leads to unsustainable "boom and bust" economic cycles, further marginalization of rural people, and over-exploitation of botanical resources to the point of extinction (Crook and Clapp 1998). The question of when and where NTFP extraction is an appropriate land use is clearly more complex than originally envisioned (Ingram et al. 2012; Neuman and Hirsch 2000 ). At its foundation, the lofty objective of integrating biodiversity conservation and rural economic development through material exploitation of nature's botanical bounty can only be realized if the extractive enterprise is both economically and environmentally sustainable.

This article reviews the research on ecological and household livelihood changes from NTFPs in the recent decade (2000-2010). Our underlying premise is that long-term successful NTFP extraction depends on both economic and ecological sustainability, but that few if any studies take both of these variables into consideration. We contribute to the interdisciplinary analysis by offering the first, to our knowledge, systematic review combining financial and ecological data on relevant extractive plant species. We first outline trends during this period in the published literature on the most relevant factors that affect NTFP economic and ecological sustainability. We then outline a methodology to compare economic sustainability across recent studies. This is followed by an overview and quantitative summary of specific non-timber forest goods, with a focus on those gathered in less developed countries (excluding wetlands).

\section{Economic Considerations}

Because extraction households are often the poorest in rural communities (cf. Pouliot 2012), incomes generated from NTFPs have the potential of reducing absolute poverty and changing income distribution. Extractors earn cash from the sale of products such as latex and medicinals; they gather free food in the form of fruits and tubers; they 
acquire energy from fuelwood; they collect free medicines from plant leaves and roots and bark; they acquire free thatch and construction poles from palm fronds and stems; and/or they obtain free ornamental decoration from wild foliage and orchids (Neumann and Hirsch 2000; Senarathne et al. 2003). Not all forest products are sold, but they nonetheless provide alternative use values to households that eliminate the need for market purchases. Unlike market items, however, extractive resources used in personal consumption and use must be priced through shadow prices of a substitute product, the loss of alternative earnings involved with collection time, or contingent valuation.

Many authors have addressed how non-timber forest product collection and trade contributes to support for current consumption, longer-term poverty reduction, and the safety-net of families (Babulo et al. 2009; Fang 2009; Lopez-Feldman et al. 2007; Sunderlin et al. 2008; Vedeld et al. 2004). First, by consuming edible forest products and other subsistence items, households avoid cash outlays, thus lowering the family's poverty line. Further, people involved in the commerce and processing of consumptive NTFPs in rural and peri-urban areas gain employment through the products' secondary links (Stoian 2005). Second, NTFPs mitigate poverty and reduce overall household risk by providing incomes during difficult times of the year, a form of natural insurance against economicallyinclement periods (Pattanayak and Sills 2001; Takasaki et al. 2004; McSweeney 2002). Income timing is crucial for NTFPs to serve as "gap fillers" and to offset cash shortfalls during "hunger seasons" (cf. Pouliot 2012; Schreckenberg et al. 2002). For households that have no other financially-worthy uses of time, additional income from NTFPs represents a bonus as well as an incentive for the household to protect the environment.

Non-timber forest resources nevertheless seldom provide sufficient income to fully support a household (Wilkie et al. 2001). Most households exhibit varying degrees of "forest dependence" (the ratio of forest income to total income). Forest dependence varies across livelihoods, as poorer households involved in extraction often choose this option due to relatively limited access to land and other assets compared to more prosperous households. An earlier meta-analyses of $61 \mathrm{CIFOR}$ case study returns to NTFPs (Belecher et al. 2005) suggested forest dependence ranging from $10-65 \%$ of total household income, whereas in 1980s case studies in Vedeld et al. (2007) it represented $22-25 \%$ of total income net of timber.

Peters' et al. (1989) pioneering study provided early optimism that extraction could be a profitable form of land use in less developed countries. They discovered that potential gross yearly returns per hectare (USD\$700) could exceed those of logging. Taking a net present value analysis and deducting labor and transportation costs pointed to over USD $\$ 6000 /$ hectare value from a representative forest site. These high returns suggested that poor people had an incentive to protect the forest rather than clear it. But other studies were less optimistic, eliciting wide variation of net returns (USD \$1-\$420/hectare/year) using different methodologies (Godoy, et al., 1993). And a later study placed the range of Central American rainforest products between only USD $\$ 17.79$ and $\$ 23.72 /$ hectare (Godoy et al. 2000).

These income figures are meant to guide planners who may consider offering incentives for particular crops or forest activities. Sheil and Wunder (2002) call for a greater focus on the returns to labor from gathering. Yet little attempt has been made either to provide a common labor analysis or to generalize the recent economic studies. 


\section{Ecological Considerations}

The economic benefits of NTFP extraction are viable over time only if collection of the species (or group of species) is ecologically sustainable. A maximum sustainable harvest limit implies that the rate at which these parts are taken from a plant, or individuals are culled from the population, will not exceed the natural rate of regeneration in a given time period. There was a long-standing, general assumption that because rural people had collected nuts, fruits, latex, fiber and the myriad other plant products for generations, the activity must not have a dramatically negative impact on the affected species or ecosystem (Voeks 1996). Certainly this was a defining rationale for the establishment of Brazil's much-publicized rubber extractive reserves (Salisbury and Schmink 2007). But human population growth and especially the increasing commercialization of these plants and plant products-regionally, nationally, and internationally-encourage strategies and intensities of harvest to meet distant markets that these species and ecosystems would seldom have witnessed in the past (Hamilton 2004). Deleterious outcomes are clearly the case for individuals that are regularly killed to retrieve the useful product, such as endangered South African cycads (Cousins et al. 2011), Mexican cacti (Jimenez-Sierra and Eguiarte 2010), Costa Rican palms (Sylvester and Avalos 2009), and many others.

Outside of directly culling individuals, there are a variety of subtle impacts at the individual, population, community and ecosystem level that detract from long-term ecological sustainability. Harvest objectives and techniques can negatively affect the physiology and vital rates of individuals, modify demographic and genetic patterns, and alter community/ecosystem-level processes (Ticktin 2004). For example, excessive tapping of latex or resin from trees can lead to their death, such as in the case of the Brazilian copaiba (Copaifera spp.), a traditional antioxidant and antiviral that is used throughout the country and exported to Europe (Plowden 2003). Leaf harvest can be sustainable if kept at low intensities, but increased harvest to meet foreign demands, for example in the case of Chamaedorea radicalis, may put individuals and the population at risk (Endress et al. 2006). And although the quantity of seed wastage under natural conditions is formidable, the excessive commercial harvest of fruits and seeds can negatively affect demographic patterns. Two such cases include Indian Phyllanthus spp., in which $86 \%-94 \%$ of total fruit yield per tree is harvested by locals (Sinha and Bawa 2002), and Brazil nuts (Bertholletia excelsa), in which up to $93 \%$ are collected (Zuidma and Boot 2002).

\section{Methodology: An Inclusive Sustainability Framework}

We focus on ecological and monetary aspects of sustainability in order to assess recent trends of specific NTFPs in different regions of the (largely) developing world. We offer a product approach by listing studies that have reported harvest rates of NTFPs (parts or whole organism) and/or income earned by household members across different time periods. Our review includes only English language, peer-reviewed journal studies 
published between the years 2000 and 2010, inclusive. Articles that were published online in 2010 but not in print until 2011 are included. We omit unpublished government and nongovernmental agency reports. We started with a Google Scholar search of the terms "nontimber forest product(s)" and "sustainability" and then branched out into other specific ecological and financial terms, as well as reviews in discipline-specific search engines. For the economics analysis, we searched under the terms "non-timber forest products" and/or "non-wood forest products" and any of the following: "economics", "financial", "value", "revenue", "returns" and "profits." For the ecological analysis, we searched "non-timber forest products" and/or "non-wood forest products" combined with the terms "sustainable", "impact", and "harvest."

For this study, we limited the scope of non-timber forest products to include only wild-harvested plants and parts, bryophytes and fungi (hereafter included as plants for convenience) inhabiting (with few exceptions) less-developed countries, especially tropical and sub-tropical Latin America, Sub-Saharan Africa, and Asia. We did not include other harvestable forest biota, such as mammals, fish, birds, and insects (or honey), or the value of ecological services, such as carbon fixation (cf. Belcher 2003; Shackleton et al. 2011). We ignored processed products along the "next stage" of a value-chain from gathering, such as returns from handicrafts, artisanal products, processed medicinal tonics and the like. We included both single species and multiple-species analyses, although it became clear early on that this was a primary feature dividing economic and ecological NTFP research. The former most often focused on forest income from the full range of plant and fungi products, whereas the latter usually concentrated on a single taxon. And we included forest products that were both marketed and non-marketed, that is, used for household consumption or bartered. This is because household total income theoretically includes not only cash income but also the value of own-produced and subsistence goods (Cavendish, 2004). In most cases, proxy values were derived for the non-marketed uses.

Additional caveats were included for the ecological and economic analysis. In the ecological analysis we only included studies that provided quantitative assessment of harvest rates and/or impacts in terms of a maximum rate of harvest threshold. Descriptive or otherwise anecdotal evidence for what was perceived by the author(s) to be either sustainable or destructive harvest was omitted. We concluded that the NTFP harvest was or was not ecologically sustainable or suitable for a sustainable extraction management scheme (at the place and time of the study) following the author's determination, although this feature in some instances required a value judgment on our part.

The economic analysis included only studies that provided a monetary value (cash or use) of the products gathered at the household or individual level. Thus we excluded some important articles that relied upon forest use values per hectare (Gavin and Anderson 2007), input-output analysis of cash flow (Obiri et al., 2007), goods use and consumption quantities (Tabuti et al. 2003), and species ranking (Lykke 2000). The included studies relied primarily on household survey data. We focused on the specific value reported (gross or net returns) for a set number of people, time and currency. Removing the cost of labor would not allow us to see the residual to workers per se. If returns net of labor are positive, then labor has received its alternative wage and by definition the activity is attractive to gatherers. These points are contentious, however, as Godoy, et al. (2000) argue that both the cost of materials and the cost of a gatherer's time should be deducted for a focus on net returns. Shackleton et al. (2002) point out, however, 
that materials costs are negligible while taking out the time cost is unnecessary, and Cavendish (2004) suggests calculating household returns based on a gross level inclusive of family (free) labor costs.

\section{Economic Sustainability: A Working Framework}

Unlike many ecological studies, most peer-reviewed articles in the economics/financial areas do not specifically answer the question of whether the activity is sustainable. To address this, we developed our own thresholds for economic sustainability, and reviewed the published articles from this perspective. We considered economic sustainability along two paths: how the observed household cash incomes or use values in dollars compare to an international poverty line and/or an alternative wage rate. Gathering is often part of a diversified household strategy of labor use and income flows. Thus analyzing a study's reported figure on yearly NTFP income (against a national income benchmark) is not sensible because it is likely the household had other income sources during the year. And whereas a few studies do report the contribution of gathering income to total income (forest dependence), this does not mean that gathering time was spent in equal proportion. For example, while gathering may have represented $20 \%$ of yearly income, it might have required more or less than $20 \%$ of household time.

What likely matters most to a gatherer is that the returns from a day's work at extraction provide enough to purchase a survival basket or at least match a day's work elsewhere. If a gatherer continues to earn below that local wage for a paid labor opportunity, he/she would abandon non-timber forest products extraction should a wage job arise (Southgate et al. 1996; Ruiz-Perez 2004). Given the paucity of studies regarding NTFP poverty-reduction impacts or alternative work opportunities, we set up two possible economic sustainability thresholds regarding the returns from a gather's work for a day:

1) International comparison: It should be above an absolute poverty line. The daily returns $Y$ for a single gatherer can be compared to the well-known international absolute poverty line of USD\$2/ per day/ per capita (purchasing power parity (PPP), per international comparisons) (World Bank 2011).Thus for each study we consider if:

\section{$Y_{i}$ per person daily NTFP income \$ PPP > \$2 PPP/day/per capita}

2) National comparison: It should meet a "time opportunity cost" standard. That is, the daily return $Y_{j}$ to the household should match a possible alternative wage earned in other paid labor opportunities, converted to dollars at a current rate. We assume that such a labor market payment would represent that earned by the whole household, since the studies did not offer data on the specific members gathering. Although numerous debates exist around whether a "minimum wage" is adequate to support a family, we consider the original intention of such a wage as a price floor to pay workers so that they are willing to sell their labor, in that they find it sufficient to live on.

Thus for each study we consider if: 
Stanley et al. 2012. Is Non-Timber Forest Product Harvest Sustainable in the Less Developed World? A Systematic Review of the Recent Economic and Ecological Literature. Ethnobio Conserv 1:9

$$
Y_{j} \text { household daily NTFP income } \$>\$ \text { daily local (or minimum) wage }
$$

Further details of the conversions necessary to make the studies comparable are discussed in Appendix 1.

Because the actual precise time (person-days) harvesting is not reported in many of the studies, we were unable to report the precise average return per harvesting day per person. Instead, we chose to develop a threshold of the number of days $(\mathrm{N})$ that would be reasonably rewarded given the reported income, converted to a $\$$ per scaled adult or household daily basis. We reframe the question as:

"What is the maximum amount of non-poverty days (or days above the going wage) that could be supported with the income reported in the study?"

Thus for each study we consider if either sustainability threshold is achieved:

1) $\mathrm{N}_{1}$ maximum days income provides at $\$ 2 /$ day/adult PPP per day $>\mathrm{N}$ days reported $\mathrm{OR}$

2) $\mathrm{N}_{2}$ maximum days income provides at $\$$ local wage/day $>\mathrm{N}$ days reported

A study income in which the \$ PPP returns per person exceeds USD $\$ 730$ clearly would have supported 365 days above absolute poverty. Thus, if gatherer income per scaled adult unit is found to be USD $\$ 100$ PPP per year, then any time working more than 50 days would have generated less than USD $\$ 2$ per day on average to have risen above an absolute poverty line. Or if gatherer income per household is found to be USD \$200 per year per household, and an alternative daily wage would be USD $\$ 4$, then having extracted for more than 50 days would have generated less than an alternative return.

\section{Results: Ecological Review}

A total of 101 studies on the ecological impacts of NTFP extraction met the necessary criteria for review (Appendix 2). Of these, the majority were carried out in Latin America (53/101, or 52.5\%), followed by Sub-Saharan Africa (25/101, or $24.8 \%$ ), and Asia $(23 / 101$, or $22.7 \%)$ (Table 1).

We followed Ticktin's (2004) similar 10-year NTFP ecological review by organizing impacts of NTFP extraction in terms of four levels of organization: individuals, populations and individuals, communities, and ecosystems (Table 1). The "Individual" category explored individual rates of growth, survival, and reproduction. Campbell (2003), for example, considered the possible effects of medicinal oleoresin extraction from Brazilian copaíba (Copaifera spp.) on individual tree longevity. The "Population and Individuals" category assessed impacts on individuals, with a view towards understanding the greater demographic implications. For instance, Larsen (2002) investigated the effects of extracting the medicinal herb (Nardostachys grandiflora) in alpine Nepal on the total root biomass of the population. The "Communities" category included studies on the effects of extraction on community structure and composition. Arjunan et al. (2005), for instance, investigated the impact of fuelwood and other extractive enterprise on overall forest 
diversity and tree height in India's southwestern Ghats. The "Ecosystem" category examines ecosystem-wide impacts of harvest, such as nutrient cycling changes or soil and habitat degradation. Thus Mutenje et al. (2011) reported that socio-economic and geographical attributes of Zimbabwean extractors were significantly associated with level of habitat degradation.

Table 1. Sustainability and regional assessment of studies that quantitatively assess the ecological impacts of harvesting NTFPs in less developed countries.

\begin{tabular}{ccccccc}
\hline Level & Region & Sustainable & Unsustainable & Unknown & Unspecified & Total \\
\hline Individuals & & $\mathbf{3}$ & $\mathbf{1}$ & $\mathbf{1}$ & $\mathbf{2}$ & $\mathbf{7}$ \\
\hline & Latin America & 1 & 1 & 1 & 1 & 4 \\
& Asia & 1 & 0 & 0 & 1 & 2 \\
& Africa & 1 & 0 & 0 & 0 & 1 \\
\hline $\begin{array}{c}\text { Populations and } \\
\text { individuals }\end{array}$ & & $\mathbf{3 9}$ & $\mathbf{8}$ & $\mathbf{9}$ & $\mathbf{2}$ & $\mathbf{5 8}$ \\
\hline & Latin America & 26 & 3 & 3 & 4 & 34 \\
& Asia & 4 & 1 & 2 & 0 & 7 \\
& Africa & 9 & 4 & 4 & 0 & 17 \\
\hline Communities & & $\mathbf{1 5}$ & $\mathbf{9}$ & $\mathbf{0}$ & $\mathbf{1}$ & $\mathbf{2 5}$ \\
\hline & Latin America & 10 & 4 & 0 & 0 & 14 \\
& Asia & 2 & 5 & 0 & 0 & 7 \\
& Africa & 3 & 0 & 0 & 1 & 4 \\
\hline Ecosystems & & $\mathbf{7}$ & $\mathbf{1}$ & $\mathbf{3}$ & $\mathbf{0}$ & $\mathbf{1 1}$ \\
\hline & Latin America & 1 & 0 & 0 & 0 & 1 \\
& Asia & 3 & 1 & 3 & 0 & 7 \\
& Africa & 3 & 0 & 0 & 0 & 3 \\
\hline & Total & $\mathbf{6 4}$ & $\mathbf{1 8}$ & $\mathbf{1 3}$ & $\mathbf{5}$ & $\mathbf{1 0 1}$ \\
\hline
\end{tabular}

The proportion of ecological studies between 2000 and 2010 that fell into these four categories was quite similar to that reported by Ticktin (2004). A majority of ecological studies in this review $(63 / 101$, or $62.4 \%)$ focused on the impacts of harvest on "populations and individuals", similar to the figure (60\%) identified by Ticktin (2004) for the decade 1990-2000. This was followed in our review by the "community" category (23/101, or $22.8 \%$ ), which differed considerably from Ticktin's (2004) figure (13\%). Much less research $(9 / 101$, or $8.9 \%)$ was carried out at the "individual level" in our study compared to Ticktin's (2004) review $(23 \%)$, and even fewer $(6 / 101$, or $5.9 \%)$ of studies in our review explored "ecosystem" impacts, similar to the figure (4.0\%) reported by Ticktin (2004).

A majority of authors self-reported that the extractive enterprise was ecologically sustainable or likely sustainable, in spite of the fact that they often recorded negative impacts associated with NTFP extraction in their studies. A total of $63.3 \%(64 / 101)$ reported that extraction was sustainable or likely to be so, compared to only $17.8 \%$ $(18 / 101)$ who reported unsustainable levels and/or intensity of harvest, or a $3.6: 1$ ratio of sustainable to unsustainable (Table 1). The remainder of researchers were either unsure, did not have sufficient data to make a reasoned judgment, or did not address the sustainability question directly. NTFP harvest was most often reported to be ecologically 
sustainable in Latin America (38/46, or $82.6 \%$ ) and least likely in Asia (10/17, or 58.8\%). Among the four levels of classification, each exhibited a very similar ratio of reportedly sustainable to unsustainable extraction-individuals (5:1), ecosystems (5:1), and individuals and populations (5.1:1). Only studies at the community level reported a disproportionately lower ratio of sustainable versus unsustainable harvest results (2.5:1).

The ecological results are also organized by life form and plant part harvested (Table 2). Palms represent the most numerous extractive life form (24/59, or $40.7 \%)$ among studies that focused on one species, followed by trees (19/59, or $32.2 \%)$ and herbs $(9 / 59$, or $15.2 \%)$. Of the studies focusing solely on a single life history, none included mushrooms and only one each for lianas and epiphytes, although more studies include these life histories in combination with others. These results are very similar to those identified by Ticktin (2004), who found that $40 \%$ of studies were of palms. In terms of plant part harvested, leaves, fronds, and foliage were the most common plant parts investigated $(23 / 59$, or $39 \%)$ followed by fruit, seeds and nuts $(16 / 59$, or $27.1 \%)$. Only three singlespecies studies explored the impacts of branch harvest, all in combination with the harvest of other parts. Only three studies examined flower and inflorescence harvest; each of these were single-species studies examining the extraction of multiple plant parts.

Numerous studies explored ecological impacts from the perspective of a single life form and two to several plant parts being harvested, such as fruit, leaf and bark harvested from a single tree species (Table 3 ). Trees were far and away the most versatile in this respect, as $71 \%$ (32/45) were exploited for more than one product. Outside of herbs $(5 / 45$, or $11.1 \%$ ) and palms $(4 / 45$, or $8.8 \%)$, no other studies investigated the exploitation of more than one plant part. Although most studies concentrated on a single or few species or life histories, a minority of research (16/101, or $15.8 \%$ ) explored the question of ecological sustainability at the household level, that is, including many or all of the principal plant species that are extracted for personal and/or commercial use and the associated plant parts collected (Table 4). Among these, trees, palms and shrubs are the most common constituents of these group collection efforts.

Table 2. Number of articles that quantitatively assess impact of NTFP harvest according to a single life form and plant part extracted*.

\begin{tabular}{lccccccccc}
\hline \multirow{2}{*}{ Life Form } & \multicolumn{1}{c}{ Plant part extracted } & \multirow{2}{*}{ Total } \\
\cline { 2 - 8 } & A & B & C & D & E & F & G & H & \\
\hline Tree & 0 & 13 & 1 & 0 & 0 & 3 & 0 & 3 & 20 \\
Shrub & 0 & 0 & 2 & 0 & 0 & 0 & 0 & 0 & 2 \\
Palm & 0 & 3 & 16 & 5 & 0 & 0 & NA & 0 & 24 \\
Herb & 1 & 0 & 2 & 4 & 2 & 0 & NA & 0 & 9 \\
Liana/Vine & 0 & 0 & 0 & 0 & 1 & 0 & 0 & 0 & 1 \\
Epiphyte & 0 & 0 & 0 & 1 & 0 & NA & NA & NA & 1 \\
Fern & NA & NA & 2 & 0 & 0 & NA & NA & NA & 2 \\
Bryophyte/Mushroom & NA & 0 & NA & 0 & NA & NA & NA & NA & 0 \\
\hline Total & 1 & 16 & 23 & 10 & 3 & 3 & 0 & 3 & 59 \\
\hline
\end{tabular}

Legend: A: Flower, inflorescence; B: Fruit, seed, nut; C: Leaf, frond, foliage; D: Whole plant, stem, meristem; E: Root, tuber, bulb, corm; F: Bark; G:Branch; H: Resin, pulp, woody parts ${ }^{* *}$; *Articles are counted in each of 
the multiple classes to which they apply (the total is not a sum of articles); NA: not applicable; **Woody refers to NTFPs derived from modified, decomposed, or pulpy woody parts, such as gaharu.

Table 3. Number of articles that quantitatively assess impact of NTFP harvest according to a single life form and multiple plant parts extracted*

\begin{tabular}{|c|c|c|c|c|c|c|c|c|c|c|}
\hline \multirow[b]{2}{*}{ Life Form } & \multicolumn{9}{|c|}{ Plant part extracted } & \multirow[b]{2}{*}{ Total } \\
\hline & $\mathbf{A}$ & B & $\mathbf{C}$ & $\mathbf{D}$ & $\mathbf{E}$ & $\mathbf{F}$ & G & $\mathrm{H}$ & I & \\
\hline Tree & 1 & 5 & 7 & 1 & 2 & 7 & 3 & 0 & 6 & 32 \\
\hline Shrub & 0 & 0 & 0 & 0 & 0 & 0 & 0 & 0 & 0 & 0 \\
\hline Palm & 0 & 1 & 1 & 1 & 1 & NA & 0 & 0 & 0 & 4 \\
\hline Herb & 1 & 1 & 1 & 2 & 0 & NA & 0 & 0 & 0 & 5 \\
\hline Liana/Vine & 0 & 0 & 0 & 0 & 0 & 0 & 0 & 0 & 0 & 0 \\
\hline Epiphyte & 0 & 0 & 0 & 0 & 0 & NA & NA & NA & 0 & 0 \\
\hline Fern & NA & NA & 0 & 0 & 0 & NA & NA & NA & 0 & 0 \\
\hline Bryophyte/Mushroom & NA & 0 & NA & 0 & NA & NA & NA & NA & 0 & 0 \\
\hline Generic or Unspecified ${ }^{* * *}$ & 0 & 0 & 0 & 0 & 0 & 0 & 0 & 0 & 4 & 4 \\
\hline Total & 2 & 7 & 9 & 4 & 3 & 7 & 3 & 0 & 10 & 45 \\
\hline
\end{tabular}

Legend: A: Flower, inflorescence; B: Fruit, seed, nut; C: Leaf, frond, foliage; D: Whole plant, stem, meristem; E: Root, tuber, bulb, corm; F: Bark; G: Branch; H: Resin, pulp, decomposed wood parts**; I: Generic or unspecified $^{* * *}$; ${ }^{*}$ Articles are counted in each of the multiple classes to which they apply (the total is not a sum of articles); ${ }^{* *}$ Woody refers to NTFPs derived from modified, decomposed, or pulpy wood parts, such as gaharu; ${ }^{* *}$ Generic or unspecified class may be one or more forms or parts.

Table 4. Articles that quantitatively assess impact of NTFP harvest according to multiple life forms and multiple parts extracted classes*

\begin{tabular}{l|l}
\hline Life form combination & Parts extracted combination \\
\hline Tree, Palm & $\begin{array}{l}\text { Fruit, seed, nut; Leaf, frond, foliage; \& Resin, pulp, woody** } \\
\text { Whole plant, stem, meristem; \& Branch }\end{array}$ \\
Tree, Shrub, Liana & $\begin{array}{l}\text { Fruit, seed, nut; Leaf, frond, foliage; Whole plant, stem, } \\
\text { meristem; \& Root, tuber, bulb, corm }\end{array}$ \\
Tree, Shrub, Herb, Bryophyte/Mushroom & $\begin{array}{l}\text { Fruit, seed, nut; Leaf, frond, foliage; Bark; \& Resin, pulp, } \\
\text { woody* }\end{array}$ \\
\hline Tree, Shrub, Palm, Herb, Liana, Epiphyte
\end{tabular}

Legend: ${ }^{*}$ One article in each of the life form combination groups; ${ }^{*}$ Woody refers to NTFPs derived from modified, decomposed, or pulpy woody parts, such as gaharu.

\section{Results: Economic Review}

Our assessment of economic sustainability in non-timber forest product harvest yielded a total of 71 studies (Appendix 3 ). The largest number of studies were carried out in Asia (38/71, or $53.5 \%$ ), followed by Latin America (19/71, or $26.7 \%$ ), and Africa (14/71, or $19.7 \%$ ) (Table 5). The methodologies employed by researchers varied considerably across the articles (Table 6).Studies reported household values across different time periods (day, month or year) and human units (household or individual). Most of the studies (47/72, or 
$69.1 \%)$ considered the household unit of analysis, with little input provided on how all household members put time into the extraction effort. And a large majority (62/72, or $86 \%$ ) of the studies considered the extraction process across a whole year, rather than a discrete daily basis. Most studies either surveyed households at different seasons or relied upon recall at year-end.

Table 5.Regional assessment of studies that quantitatively assess the economic implications of harvesting non-timber forest products

\begin{tabular}{lc}
\hline Region & Number of studies \\
\hline Latin America & 19 \\
Asia & 38 \\
Africa (Sub-Saharan and North) & 14 \\
\hline Total & 71 \\
\hline
\end{tabular}

Across all the regions studied, $68.1 \%(48 / 72)$ provided data to suggest that household earnings per year from NTFP collection averaged USD $\$ 791$ (at current rates) (Appendix 3). Alternatively, the returns per person (scaled) came out to USD $\$ 151$ ( $\$ 408$ PPP) per year. These amounts are well-above the trends reported in earlier meta-analyses (Vedeld et al. 2007; Ruiz-Perez et al. 2004). Of the studies that focused on a daily analysis, the returns appeared to be USD $\$ 11.20$ /person/day on average; this level includes the omission of the extremely-high outlier returns to tila (Ternstroemia lineata) and blackberry (Rubus spp.) picking in Mexico (Marshall and Newton 2003).

Table 6.Focus of studies that quantitatively assess the economic implications of harvesting nontimber forest products

\begin{tabular}{ccc}
\hline Level & Type of assessment & Number studies \\
\hline Individual & Daily/weekly gross cash income & 9 \\
& Yearly gross or net cash income & 15 \\
Household (or family) & Daily gross cash income & 0 \\
& Yearly gross cash income & 23 \\
& Yearly net cash income & 4 \\
& Yearly total value (cash + use) & 20 \\
\hline
\end{tabular}

Employing the benchmarks outlined above, economic sustainability assessment was possible in just over half of the studies (47/71, or $66.2 \%)$ (Table 7 ). Of these, a large majority $(36 / 47$, or $76.6 \%)$ of extractive enterprises were determined by the criteria employed in this review to be economically sustainable. Among economic studies for which sustainability could be assessed, a greater percentage were sustainable at the individual level $(15 / 18$, or $83.3 \%$ ) compared to the household level $(21 / 29$, or $72.4 \%)$. There were regional trends as well. For Africa, $71 \%$ of the studies could be assessed, with $70 \%$ suggesting that gathering household incomes associated with days remunerated 
were above an international poverty line or a going wage rate. Asian studies were less clear, with only $54 \%$ providing sufficient data. Of these, $80 \%$ of households appear to get returns adequate to justify continued participation, according to our thresholds. For Latin America, $89.5 \%$ of cases demonstrated similar extraction success, and $76 \%$ of households earned incomes associated with the days' returns above absolute poverty or above alternate wage rates. Some products were shown to be economically sustainable in one study, but not in another, such as wild asparagus (Asparagus racemosus) gathering in Nepal. Numerous other products, such as thatch grass in Malawi, betel leaf (Piper betel) in Bangladesh, bark and uppage fruit (Garcinia gummi-gutta) in India, and mushrooms in Mexico, to name a few, could not be assessed given study limitations.

Table 7. Results of studies that quantitatively assess the economic implications of harvesting nontimber forest products

\begin{tabular}{lcccc}
\hline \multicolumn{1}{c}{ Level } & Sustainable & Unsustainable & $\begin{array}{c}\text { Could not be } \\
\text { assessed }\end{array}$ & Total \\
\hline Individual & 15 & 3 & 6 & 24 \\
Household & 21 & 8 & 18 & 47 \\
\hline Total & 36 & 11 & 24 & 71 \\
\hline
\end{tabular}

\section{Discussion and Conclusions}

Assessment of recent studies of non-timber forest products (2000-2010) in the tropical and subtropical world suggests that these extractive activities are overall ecologically and economically sustainable under current or practical conditions. This is the case in Latin America, Africa, and Asia. A considerable majority of studies report that current levels and intensities of harvest do not threaten the ability of individuals and populations to replace themselves, nor is the ecological integrity of the relevant ecosystems threatened. Researchers were less sanguine regarding the impacts of extractive activities on associated community members, such as removal of food sources for frugivorous birds and mammals. They also report complementary negative community effects, such as the local extinction of large mammals due to overhunting by palm heart extractors (Matos and Bovi 2002) or unsustainable agricultural practices and timber removal during non-gathering periods of Brazil nuts (Escobar and Aldana 2003). Most researchers acknowledge the challenges associated with assessing ecological sustainability in a fixed temporal setting while conditions and feedbacks, such as ecological dynamics and supply and demand, are ever-evolving. Such acknowledgement requires nuanced assessments weighing the potential ecological threats to and associated with NTFP extraction. In this vein, positive sustainable impact assessments most typically propose management strategies or practices that, if implemented, could maximize the benefits of NTFP extraction while providing or maximizing ecological conservation and associated benefits.

What researchers know about the relative sustainability of NTFP harvest for this review period is geographically contingent. Much more is known about the ecological consequences of extractivism in Latin America than in Asia or Africa. And within these 
regions, a few countries have received abundant research attention, such as Brazil, Bolivia, Benin, South Africa, India and Nepal. But because so many less developed countries are not represented by a single study, our conclusions regarding ecological sustainability of NTFP harvest must be taken with caution. Nevertheless, the fact that many of the features associated with NTFP extraction identified in this review were quite similar to those reported by Ticktin (2004) in her review of the 1990s literature suggests both that these studies represent a reasonably good barometer of current extractive patterns and that there is considerable continuity of harvest characteristics over time. Thus, most studies continue to be carried out on the ecological consequences of NTFP harvest on plant populations and individuals. Research at the community and ecosystem level continues to receive much less attention. Trees and palms are investigated far more frequently than other life forms, and they both supply multiple harvestable products. Nearly all research is directed at the extraction of seeds/fruit/nuts, leaves, and meristem (especially palm heart) harvest. The ecological effects of lianas, epiphytes and mushroom harvest are almost never investigated in the tropics and subtropics.

In regards to financial returns, our review suggests that NTFP collection represents an attractive option for keeping gatherers out of poverty. Earnings represent an economically justifiable use of gatherer time, except in the very poorest countries of East Asia. This could be due to the overall degree of poverty there (mean household annual incomes are usually less than USD $\$ 1000$ per capita/year). In wealthier less-developed countries, such as several in Latin America, overall yearly mean incomes are higher, so it is more likely that NTFP gathering will elevate people above the international poverty line standard. These regional differences are important since going rural wage rates have long been higher in Latin America. Vedeld et al. (2004) found the highest overall NTFP incomes (across meta-analysis case studies) in Latin America (USD\$5,676 PPP) with the lowest in East Africa (USD\$1697 PPP). And Ruiz-Perez et al. (2004) report USD\$10.25/day in Latin America against USD $\$ 5.62$ per day in Africa.

These economic findings must, however, be kept in perspective. A few successful days of extraction may be an attractive, short-term option, but they are unlikely to remove families from long-term poverty, or to change national poverty rate statistics if families have limited resource access or limited tenure security. Some products require extensive areas from which to gather in order to acquire sufficient material, but few of the studies reviewed here provided details on the geographical range within which gatherers extracted or whether these spatial features had changed over time (but see Jensen and Melby 2010). The reality of limited and uncertain resource access is revealed by the fact that most households continue to rely upon other activities for most of their income. In the African studies, for example, the mean across all studies was $25.0 \%$ of the total household income derived from NTFPs, which was close to that in Asia (24.3\%) and Latin America (24.8\%). But the variation was considerable. NTFP values can account for only $2-7 \%$ of total income, even among "forest dependent" households such as those in Sri Lanka (Illukpitya and Yanagida 2010). Elsewhere this dependence is greater, such as gathering of Brazil nuts $(51 \%)$ in Peru, wild asparagus $(67 \%)$ in Nepal, and gaharu resin $(71 \%)$ in Indonesia (Escobal and Aldana 2003; Maraseni et al. 2008; Wollenberg 2001). Finally, we know much more about the economic sustainability of NTFP harvest in Asia, which was the subject of more research during this review period, than Africa and Latin America combined. 
If the 150 plus studies examined in this systematic review are representative, then researchers are guardedly optimistic in regards to the ecological and economic sustainability of NTFP extraction. However, our survey is not representative of every recent finding regarding sustainability, as we specifically included only articles with household financial values and omitted many trends observed in book chapters and technical reports. And caution must be exercised in terms of extending these results into future decades. Changing economic conditions, rates and sources of deforestation, and climate change all point to increased pressures upon forests. In Tibet's "Medicine Mountains", overharvest of medicinal species combined with temperature increases $\left(5-6^{\circ}\right.$ $\mathrm{C}$ by the end of the century) threatens the ethnobotanical foundation of Tibetan culture and religion (Salick et al. 2009). And in the Brazilian Amazon, rubber tappers once famously fought to forestall deforestation for cattle expansion. Today, as income from rubber fails to fill financial needs, tappers have diversified into cattle ranching, representing a newfound source of Amazonia's "cattle-ization" problem (Gomes et al. 2012).

Our analysis also points out persistent methodological problems in studies of the returns of non-timber forest products. First, many economic analyses bundle products together and fail to delineate specific outcomes by single products and species. The absence in so many economic reports of scientific names limits the scope of analysis as well as the opportunity for interdisciplinary comparison. And as stated earlier, sustainability must be measured (at the least) in ecological and economic terms, yet there is very little chance to consider both of these factors in a single extractive enterprise. With very few exceptions, economists assess financial dimensions of NTFP collection, and biologists assess ecological issues, with limited overlap. Collaboration between these researchers during the study design process seems the obvious solution.

Second, many analyses fail to account for household labor time by period or by person across a full year. A broad aggregation is presented in most published research. Only a few investigators consider the number of collecting trips per year (to compare to the value of the gathered product per year). These research practices prevent a thorough analysis of daily returns which is crucial for clear comparison of alternative uses of rural residents' labor. Additionally, studies fail to specify the number of household members working in gathering compared to the members consuming from the income streams generated. Future survey instruments should include time use patterns and collection rates and returns across all seasons.

Third, the question of ecological sustainability is clearly fundamental to long-term success of extractivist activities. Each of the ecological studies cited here discusses this feature either in their introduction or conclusion, and most employ field methods and quantitative analyses to explore the question. Yet a surprising number of studies fail to make explicit statements regarding the relative sustainability of the harvest activity. In the interests of the myriad stakeholders involved, we encourage authors to articulate, to the degree possible, whether harvest of the NTFP under current conditions is sustainable, and to make recommendations that would foster future sustainability.

Finally, we note that most studies in the ecological analysis report physical extraction rates over a short study period, usually two years or less. Ultimately a longer term analysis is needed, particularly since extraction quantities and prices can affect household incomes. The Homma model of extractive production suggests a rapid expansion, followed by stabilization and then decline in the ratio of production/extraction 
(Homma, 1996). If extraction and cultivation eventually occur at the same time, prices will fall. While standard economic theory suggests that higher prices create a greater quantity supplied, what often matters to poor people is meeting a subsistence income threshold. In other words, falling prices could also create pressure for over-extraction as gatherers seek to get a minimum cash flow. Crook and Clapp (1998) suggest low returns would cause overexploitation of a target species, and others (Belcher and Schreckenberg 2007) suggest commercialization and specialization brought by high prices would do so in "boom and bust" fashion. Future research is needed on the dynamic interaction between economic and ecological sustainability across studies or within a single study.

\section{References}

Ackermann K (2004) Utilization of wild growing yams as supplementary nutrition and its impact on the dry forest ecosystem in north-western Madagascar. Schweizerische Zeitschrift fur Forstwesen 155: 80-88.

Ahenkan A, Boon E (2011) Non-timber forest products farming and empowerment of rural women in Ghana. Environmental Development and Sustainability 13: 863-878.

Ambrose-Oji B (2003) The contribution of NTFPs to the livelihoods of the forest poor:

Evidence from the tropical forest zone of south-west Cameroon. International Forestry Review 5: 106-117.

Amusa TO, Jimoh SO, Aridanzi P, Haruna M (2010) Ethnobotany and conservation of plant resources of Kainji Lake National Park, Nigeria. Ethnobotany Research \& Applications 8: 181-194.

Anderson P, Putz FE (2002) Harvesting and conservation: Are both possible for the palm, Iriartea deltoidea? Forest Ecology and Management 170: 271-283.

Andrade BS, Hay JDV (2007) Estimation of aerial biomass of Lychnophora ericoides (Mart.) Braz. Arch. Biol. Technol. 50: 687-694.

Anten N, Martínez-Ramos M, Ackerly DD (2003) Defoliation and growth in an understory palm: Quantifying the contributions of compensatory responses. Ecology 84: 2905-2918.

Arjunan M, Puyravaud JP, Davidari P (2005) The impact of resource collection by local communities on the dry forests of the Kalakad-Mundanthurai Tiger Reserve. Tropical Ecology 46: 135-143.

Arora D (2008) The houses that matsutake built. Economic Botany 62: 278-290.

Avocèvou-Ayisso C, Sinsin B, Adégbidi A, Dossou G, Van Damme P (2009) Sustainable use of non-timber forest products: Impact of fruit harvesting on Pentadesma butyracea regeneration and financial analysis of its products trade in Benin Forest. Ecology and Management 257:1930-1938.

Babulo B, Muys B, Nega F, Tollens E, Nyssen J, Deckers J, Mathijs E (2009) The economic contribution of forest resource use to rural livelihoods in Tigray, Northern Ethiopia. Forest Policy and Economics 11: 109-117.

Baldauf C, Dos Reis MS (2010) Effects of harvesting on population structure of leatherleaf fern (Rumohra adiantiformis (G. Forst.) Ching) in Brazilian Atlantic rainforest. American Fern Journal 100:148-158.

Belcher B (2003) Comment: What isn't an NTFP? International Forestry Review 5: 161168. 
Belcher B, Ruiz-Perez M, Achdiawan R (2005) Global patterns and trends in the use and management of commercial NTFPs: Implications for livelihoods and conservation. World Development 33: 1435-1452.

Belcher B, Schreckenberg K (2007) Commercialisation of non-timber forest products: A reality check. Development Policy Review 24: 355-377.

Bhat PR, Murali KS, Hegde GT, Shastri CM, Bhat DM, Murthy IK, Ravindranath NH (2003) Annual variation in non-timber forest product yield in the Western Ghats, Karnataka, India. Current Science 85: 1350-1355.

Bongers $F$ (ed) (2010) Degraded forests in eastern Africa: Management and restoration. Earthscan, London, UK.

Calvo-Irabién LM, Zapata MT, Iriarte-Vivar S (2009) Effects of leaf harvest on Thrinax radiata palm: Implications for management and conservation. Journal of Tropical Forest Science 21: 34-44.

Cavendish W (2000) Empirical regularities in the poverty-environment relationship in rural households: Evidence from Zimbabwe.World Development 28: 1979-2003.

Cavendish W (2004) Quantitative methods for estimating the economic value of resource use to rural households. In: Campbell B, Luckert M (eds) Uncovering the hidden harvest: Valuation methods for woodland and forest resources. Earthscan Publications, London, ch. 2.

Chauhan K, Sharma A, Kumar R (2008) Non-timber forest products subsistence and commercial uses: Trends and future demands. International Forestry Review 10: 201-216.

Chhetri HB, Gupta VNP (2006) NTFP potential of Upper Mustang - A trans-Himalayan region in western Nepal. Scientific World 4: 38-43.

Coomes O, Barhan B, Takasaki Y (2004) Targeting conservation-development initiatives in tropical forests: Insights from analyses of rain forest use and economic reliance among Amazonian peasants. Ecological Economics 51: 47-64.

Cousins S, Williams V, Witkowski E (2011) Quantifying the trade in cycads (Encephalartos species) in the traditional medicine markets of Johannesburg and Durban, South Africa. Economic Botany 65: 356-370.

Crook C, Clapp R (1998) Is market-orientated forest conservation a contradiction in terms? Environmental Conservation 25: 131-145.

Dalle SP, Potvin C (2004) Conservation of useful plants: An evaluation of local priorities from two indigenous communities in Eastern Panama. Economic Botany 58: 38-57.

Datta D, Guha P, Chattopadhyay RN (2010) Application of criteria and indicators in community based sustainable mangrove management in the Sundarbans, India. Ocean \& Coastal Management 53: 468-477.

Delang C (2006) The role of wild food plants in poverty alleviation and biodiversity conservation in tropical countries. Progress in Development Studies 6: 275-286.

Delvaux C, Sinsin B, Darchambeau F, Van-Damme P (2009) Recovery from bark harvesting of 12 medicinal tree species in Benin, West Africa. Journal of Applied Ecology 46: 703-712.

Delvaux C, Sinsin B, Van-Damme P (2010) Impact of season, stem diameter and intensity of debarking on survival and bark re-growth pattern of medicinal tree species, Benin, West Africa. Biological Conservation 143: 2664-2671. 
Dhillion SS, Gustad G (2004) Local management practices influence the viability of the baobab (Adansonia digitata Linn.) in different land use types, Cinzana, Mali. Agriculture, Ecosystems \& Environment 101: 85-103.

Diamini C, Geldenhuys C (2011) Quantities and values of selected forest medicines harvested by eight villages adjacent to natural woodlands in the four ecological zones of rural Swaziland. African Journal of Plant Science 5: 730-741.

Reis MS, Fantini AC, Nodari RO, Reis A, Guerra MP, Mantovani A (2000) Management and conservation of natural populations in Atlantic Rain Forest: The case study of palm heart (Euterpe edulis Martius). Biotropica 32: 894-902.

Emanuel PL, Shackleton CM, Baxter JS (2005) Modelling the sustainable harvest of Sclerocarya birrea subsp. caffra fruits in the South African lowveld. Forest Ecology and Management 214: 91-103.

Endress B, Gorchov DL, Noble RB (2004a) Non-timber forest product extraction: Effects of harvest and browsing on an understory palm. Ecological Applications 14: 1139-1153.

Endress B, Gorchov DL, Peterson MB, Serrano EP (2004b) Harvest of the palm Chamaedorea radicalis, its effects on leaf production, and implications for sustainable management. Conservation Biology 18: 822-830.

Endress B, Gorchov DL, Berry EL (2006) Sustainability of a non-timber forest product: Effects of alternative leaf harvest practices over 6 years on yield and demography of the palm Chamaedorea radicalis. Forest Ecology and Management 234: 181-191.

Escobal J, Aldana U (2003) Are nontimber forest products the antidote to rainforest degradation? Brazil nut extraction in Madre De Dios, Peru. World Development 31: 1873-1887.

Escalante S, Montaña C, Orellana R (2004) Demography and potential extractive use of the liana palm, Desmoncus orthacanthus Martius (Arecaceae), in southern Quintana Roo, Mexico. Forest Ecology and Management 187: 3-18.

Fandohan B, Assogradjo A, Kakai R, Kyndt T, Calluwe E, Codija J, Sinsin B (2010) Women's traditional knowledge, use value, and the contribution of tamarind to rural households' cash income in Benin. Economic Botany 64: 248-259.

Fang B (2009) Poverty and biodiversity in rural areas based on two investigations in Pujiang County, China. Journal of Environmental Management 90:1924-1932.

Fantini AC, Guries RP (2007) Forest structure and productivity of palmiteiro (Euterpe edulis Martius) in the Brazilian Mata Atlântica. Forest Ecology and Management 242: 185-194.

Forget PM, Jansen PA (2007) Hunting increases dispersal limitation in the tree Carapa procera, a nontimber forest product. Conservation Biology 21: 106-113.

Fu Y, Chen J, Guo H, Chen A, Cui J, Hu H (2009) The role of non-timber forest products during agroecosystem shift in Xishuangbana, SW China. Forest Policy and Economics 11: 18-25.

Gaoue OG, Ticktin T (2007) Patterns of harvesting foliage and bark from the multipurpose tree Khaya senegalensis in Benin: Variation across ecological regions and its impacts on population structure. Biological Conservation 137:424436. 
Gaoue OG, Ticktin T (2008) Impacts of bark and foliage harvest on Khaya senegalensis (Meliaceae) reproductive performance in Benin. Journal of Applied Ecology 45: 34-40.

Gaoue OG, Ticktin T (2009) Fulani knowledge of the ecological impacts of Khaya senegalensis (Meliaceae) foliage harvest in Benin and its implications for sustainable harvest. Economic Botany 63: 256-270.

Gaoue OG, Ticktin T (2010) Effects of harvest of nontimber forest products and ecological differences between sites on the demography of African mahogany. Conservation Biology 24:605-614.

Gavin M, Anderson G (2007) Socioeconomic predictors of forest use values in the Peruvian Amazon: A potential tool for biodiversity conservation. Ecological Economics 60: 752-762.

Godoy R, Labowski R, Markandya A (1993) A method for the economic valuation of non-timber forest products. Economic Botany 47: 220-233.

Godoy R, Wilkie D, Overman H, Cubas A, Denmer J (2000) Valuation of consumption and sale of forest goods from a Central American rain forest. Nature 406: 62-63.

Gomez C, Perz S, Vadjunec J (2012) Convergence and contrasts in the adoption of cattle ranching: Comparisions of smallholder agriculturalists and forest extractivists in the Amazon. Journal of Latin American Geography 11: 99-120.

Guariguata MR, Licona JC, Mostacedo B, Cronkleton P (2009) Damage to Brazil nut trees (Bertholletia excelsa) during selective timber harvesting in northern Bolivia. Forest Ecology and Management 258: 788-793.

Gubbi S, MacMillan C (2008) Can non-timber forest products solve livelihood problems? A case study from Periyar Tiger Reserve, India. Oryx 42: 222-228.

Guedje NM, Lejoly J, Nkongmeneck BA, Jonkers WBJ (2003) Population dynamics of Garcinia lucida (Clusiaceae) in Cameroon Atlantic forests. Forest Ecology and Management 177:231-241.

Guedje NM, Zuidema PA, During H, Foahom B, Lejoly J (2007) Tree bark as a nontimber forest product: The effect of bark collection on population structure and dynamics of Garcinia lucida Vesque. Forest Ecology and Management 240: 1-12.

Hagen BV, Fight RR (1999) Opportunities for conservation based development of nontimber forest products in the Pacific Northwest. US Department of Agriculture, Forest Service, Pacific Northwest Research Station, Portland OR.

Hamilton AC (2004) Medicinal plants, conservation and livelihoods. Biodiversity and Conservation 13: 1477-1517.

He J (2010) Globalised forest-products: Commodification of the matsutake mushroom in Tibetan villages, Yannan, SW China. International Forestry Review 13: 27-37.

Holm J, Miller CJ, Cropper Jr. WP (2008) Population dynamics of the dioecious Amazonian palm Mauritia flexuosa: Simulation analysis of sustainable harvesting. Biotropica 40: 550-558.

Homma AKO (1996) Modernization and technological dualism in the extractive economy in Amazonia. In: Ruiz-Perez M, Arnold J (eds) Current Issues in NonTimber Forest Product Research. CIFOR, Bogor, Indonesia, pp. 59-81. 
Howell C, Schwabe K, Samah A (2010) Non-timber forest product dependence among the Jah Hut subgroup of Peninsular Malaysia's Orang Asli. Environment, Development and Sustainability 12: 1-18.

Heubach K, Witting R, Nuppenau E, Hahn K (2011) The economic importance of nontimber forest products (NTFPs) for livelihood maintenance of rural west African communities: A case study from northern Benin. Ecological Economics 70: 19912001.

Huber F, Ineichen R, Yang Y, Weckerle C (2010) Livelihood and Conservation Aspects of Non-wood Forest Product Collection in the Shaxi Valley, Southwest China. Economic Botany 64: 189-204.

Illukpitiya P, Yanagida J (2010) Farming vs. forests: Trade-off between agriculture and the extraction of non-timber forest products. Ecological Economics 69: 1952-1963.

Ingram V, Ndoye O, Iponga DM, Tieguhong JC, Nasi R (2012) Non-timber forest products: Contribution to national economy and strategies for sustainable management. In: Wasseige $C$, Marcken $P$, Bayol N, Hiol F, Mayaux P, Desclée B, Nasi R, Billand A, Defourny P, Eba'a R. The Forests of the Congo Basin: State of the Forest 2010. Luxembourg: Office des publications de l'Union Européenne.

Jensen A, Melby H (2010) Returns from harvesting a commercial non-timber forest product and particular characteristics of harvesters and their strategies: Aquilaria crassna and agarwood in Lao PDR. Economic Botany 64: 34-45.

Jimenez-Sierra C, Eguiarte, L (2010) Candy barrel cactus (Echinocactus platyacanthus Link \& Otto): A traditional plant resource in Mexico subject to uncontrolled extraction and browsing. Economic Botany 64: 99-108.

Jiménez-Valdés M, Godínez-Alvarez H, Caballero J, Lira R (2010) Population dynamics of Agave marmorata Roezl. under two contrasting management systems in Central Mexico. Economic Botany 64:149-160.

Jones FA, Gorchov DL (2000) Patterns of abundance and human use of the vulnerable understory palm, Chamaedorea radicalis (Arecaceae), in a montane cloud forest, Tamaulipas, Mexico. The Southwestern Naturalist 45: 421-430.

Kamanga $P$, Vedeld $P$, Sjaastad E (2009) Forest incomes and rural livelihoods in Chiradzulu District, Malawi. Ecological Economics 68: 613-624.

Karanth KK, Curran LM, Reuning-Scherer JD (2006) Village size and forest disturbance in Bhadra Wildlife Sanctuary, Western Ghats, India. Biological Conservation 128: 147-157.

Kim S, Sasaki N, Koike M (2008) Assessment of non-timber forest products in Phnom Kok community forest, Cambodia. Asia Europe Journal 6: 345-354.

Kouassi KI, Barot S, Gignoux J, Bi IAZ (2008) Demography and life history of two rattan species, Eremospatha macrocarpa and Laccosperma secundiflorum, in Côte d'Ivoire. Journal of Tropical Ecology 24: 493-503.

Kronborg M, Grandez C, Ferreira E, Balslev H (2008) Arecaceae-a little known source of piassaba fibers from Western Amazon. Revista Peruana de Biologica 15: 103113.

Kusters K (2008) Will agroforests vanish? The case of Damar agroforests in Indonesia. Human Ecology 36: 357-370. 
Larsen HO (2002) Commercial medicinal plant extraction in the hills of Nepal: Local management system and ecological sustainability. Environmental Management 29:88-101.

Lázaro-Zermeño JM, González-Espinosa M, Mendozac A, Martínez-Ramos M, QuintanaAscencio PF (2010) Individual growth, reproduction and population dynamics of Dioon merolae (Zamiaceae) under different leaf harvest histories in Central Chiapas, Mexico. Forest Ecology and Management 261: 427-439.

Lemenih M, Abebe T, Olsson M (2003) Gum and resin resources from some Acacia, Boswellia and Commiphora species and their economic contributions in Liban, SE Ethiopia. Journal of Arid Environments 55: 465-482.

Lermyte C, Forget PM (2009) Rapid assessment of dispersal failure and seedling recruitment of large-seeded non-timber forest products trees in a tropical rainforest. Tropical Conservation Science 2: 404-424.

López-Feldman, A, Mora, J, Taylor, J.E (2007) Does natural resource extraction mitigate poverty and inequality? Evidence from rural Mexico and a Lacandona rainforest community. Environment and Development Economics 12: 251-269.

Lopez-Toledo L, Horn C, López-Cen A, Collí-Díaz R, Padilla A (2011) Potential management of Chamaedorea seifrizii (Palmae), a non-timber forest product from the tropical forest of Calakmul, Southeast Mexico. Economic Botany 65: 371380.

Lykke A (2000) Local perceptions of vegetation change and priorities for conservation of woody-savanna vegetation in Senegal. Journal of Environmental Management 59: 107-120.

Mamo G, Sjaastad E, Vedeld P (2007) Economic dependence on forest resources: A case from Dendi District, Ethiopia. Forest Policy and Economics 9: 916-927.

Maraseni T (2006) Nepalese non-timber forest products: An analysis of the equitability of profit distribution across a supply chain in India. Small-scale Forest Economics, Management, Policy 5: 191-206.

Marshall E, Newton AC (2003) Non-timber forest products in the community of EI Terrero, Sierra de Manantlán Biosphere Reserve, Mexico: Is their use sustainable? Economic Botany 57: 262-27.

Martínez-Ramos M, Anten NPR, Ackerly DD (2009) Defoliation and ENSO effects on vital rates of an understory tropical rain forest palm. Journal of Ecology 97: 10501061.

Matos DMS, Bovi MLA (2002) Understanding the threats to biological diversity in southeastern Brazil. Biodiversity and Conservation 11:1747-1758.

Mcelwee P (2008) Forest environmental income in Vietnam: Household socioeconomic factors influencing forest use. Environmental Conservation 35: 147-159.

McSweeney K (2002) Who is forest-dependent? Capturing local variation in forestproduct sale, Eastern Honduras. The Professional Geographer 54: 158-174.

Medeiros RS, Vieira G (2008) Sustainability of extraction and production of copaiba (Copaifera multijuga Hayne) oleoresin in Manaus, AM, Brazil. Forest Ecology and Management 256: 282-288.

Menton MC (2003) Effects of logging on non-timber forest product extraction in the Brazilian Amazon: Community perceptions of change. International Forestry Review 5: 97-105. 
Mishra M, Kotwal PC, Prasad C (2010) Harvesting of medicinal plants in the forest of central India and its impact on quality of raw materials: A case of Nagpur District, India. ECOPRINT 16: 35-42.

Misra MK, Dash SS (2000) Biomass and energetics of non-timber forest resources in a cluster of tribal villages on the Eastern Ghats of Orissa, India. Biomass and Bioenergy 18: 229-247.

Moegenburg S, Levey DJ (2002) Prospects for conserving biodiversity in Amazonian extractive reserves. Ecology Letters 5: 320-324.

Montoya A, Hernandez H, Mapes C, Kong A, Estrada-Torres A (2008) The collection and sale of wild mushrooms in a community of Tlaxcala, Mexico. Economic Botany 62: 413-424.

Mukui S, Uddin M, Rashid A, Fox J (2010) Integrating livelihoods and conservation in protected areas: Understanding the role and stakeholder views on prospects for non-timber forest products, a Bangladesh case study. International Journal of Sustainable Development \& World Ecology 17: 180-188.

Mukwada G (2009) The influence of anthropogenic phenomena and contingency in tree resource distribution in Mufurudzi resettlement area, Zimbabwe. Journal for Nature Conservation 17: 1-14.

Murthy I, Bhat P, Ravindranath N, Sukumar R (2005) Financial valuation of non-timber forest product flows in Uttara Kannada district, Western Ghats, Karnataka. Current Science 88: 1573-1579.

Mutenje MJ, Ortmann GF, Ferrer SRD (2010) Management of non-timber forestry products extraction: Local institutions, ecological knowledge and market structure in South-Eastern Zimbabwe. Ecological Economics 70: 454-461.

Myers GP, Newton AC, Melgarejo $O$ (2000) The influence of canopy gap size on natural regeneration of Brazil nut (Bertholletia excelsa) in Bolivia. Forest Ecology and Management 127: 119-128.

Nahuelhual L, Palma J, Gonzalez M, Ortiz K (2008) Potential for greenery from degraded temperate forests to increase income of indigenous women in Chile. Agroforestry Systems 75: 97-109.

Nakazono E, Bruna EM, Mesquita RCG (2004) Experimental harvesting of the nontimber forest product Ischnosiphon polyphyllus in central Amazonia. Forest Ecology and Management 190: 219-225.

Ndangalasi HJ, Bitariho R, Dovie DBK (2007) Harvesting of non-timber forest products and implications for conservation in two montane forests of East Africa. Biological Conservation 134: 242-250.

Neumann R, Hirsch E (2000) Commercialisation of non-timber forest products: Review and analysis of research. CIFOR and FAO, Bogor, Indonesia.

Nygren A, Lacuna-Richman C, Keinanen K, Alisa L (2006) Ecological, socio-cultural, economic and political factors influencing the contribution of non-timber forest products to local livelihoods: Case studies from Honduras and the Philippines. Small-scale Forest Economics, Management and Policy 4: 249-269.

Obiri B, Bright G, McDonald M, Anglaaere L, Cobbina J (2007) Financial analysis of shaded cocoa in Ghana. Agroforestry Systems 71: 139-149. 
Olupot W, Barigyira R, McNeilage AJ (2009) Edge-related variation in medicinal and other "useful" wild plants of Bwindi Impenetrable National, Park, Uganda. Conservation Biology 23: 1138-1145.

Omeja P, Obua J, Cunningham AB (2004) Regeneration, density and size class distribution of tree species used for drum making in central Uganda. African Journal of Ecology 42: 129-136.

Pabuayon I (2004) Consumption value and income potential of bamboo in the Philippines: Evidence from selected areas. Journal of Bamboo and Rattan 3: 249263.

Pandit $\mathrm{BH}$ (2008) Economics of non-timber forest production promotion and marketing: A case study from Malekhukhola Watershed of Dhading District, Nepal. The Initiation 2: 145-156.

Pandit BH, Thapa GB (2003) A tragedy of non-timber forest resources in the mountain commons of Nepal. Environmental Conservation 30: 283-292.

Paoli G, Peart DR, Leighton M, Samsoedin I (2001) An ecological and economic assessment of the nontimber forest product gaharu wood in Gunung Palung National Park, West Kalimantan, Indonesia. Conservation Biology 15: 1721-1732.

Pattanayak S, Sills E (2001) Do tropical forests provide natural insurance? The microeconomics of non-timber forest product collection in the Brazilian Amazon. Land Economics 77: 595-612.

Pedersen $\mathrm{H}$, Skov $\mathrm{F}$ (2001) Mapping palm extractivism in Ecuador using pair-wise comparisons \& bioclimatic modeling. Economic Botany 55: 63-71.

Peres C et al. (2003) Demographic threats to the sustainability of Brazil nut exploitation. Science 302: 2112-2114.

Peters CM, Gentry AH, Mendelsohn RO (1989) Valuation of an Amazon rainforest. Nature 339: 655-656.

Pfab MF, Scholes MA (2004) Is the collection of Aloe peglerae from the wild sustainable? An evaluation using stochastic population modeling. Biological Conservation 118: 695-70.

Plowden C (2003) Production ecology of copaíba (Copaifera spp.) oleoresin in the eastern Brazilian Amazon. Economic Botany 57: 491-501.

Plowden C, Uhl C, Oliveira F (2003) The ecology and harvest potential of titica vine roots (Heteropsis flexuosa: Araceae) in the eastern Brazilian Amazon Forest. Ecology and Management 182: 59-73.

Portela RDCQ, Bruna EM, Santos FAM (2010) Demography of palm species in Brazil's Atlantic forest: A comparison of harvested and unharvested species using matrix models. Biodiversity and Conservation 19: 2389-2403.

Pouliot, M. (2012) Contribution of "women's gold" to West African livelihoods: The case of shea (Vitellaria paradoxa) in Burkina Faso. Economic Botany 63(3): 237248.

Pyhala A, Brown K, Adger W (2006) Implications of livelihood dependence on nontimber products in Peruvian Amazonia. Ecosystems 9: 1328-1341.

Rahman M, Rahman M, Islam M (2009) Financial viability and conservation role of betel leaf based agroforestry: An indigenous hill farming system of Khasia community in Bangladesh. Journal of Forestry Research 20: 131-136. 
Rai N, Uhl CF (2004) Forest product use, conservation and livelihoods: The case of uppage fruit harvest in the Western Ghats, India. Conservation \& Society 2: 289313.

Rani A, Chawhan PH, Rathore M (2009) Sustainable harvesting of Nagarmotha (Cyperus scariosus R. Br.). Indian Forester 135:1579-1584.

Reyes-Garcia V, Huanca T, Vadez V, Leonard W, Wilkie D (2006) Cultural, practical and economic value of wild plants: A quantitative study in the Bolivian Amazon. Economic Botany 60: 62-74.

Riadh S (2007) Assessing the role of non-timber forest products in the livelihoods of communities living inside and outside of Lawachara National Park. In: Fox J, Bushley B, Dutt S, Quazi S (eds) Making conservation work: Linking rural livelihoods and protected areas in Bangladesh, Honolulu: East-West Center, pp. 36-49.

Robinson EJZ, Lokina RB (2010) A spatial-temporal analysis of the impact of access restrictions on forest landscapes and household welfare in Tanzania. Forest Policy and Economics 13: 79-85.

Rodríguez-Buriticá S, Orjuela MA, Galeano G (2005) Demography and life history of Geonoma orbignyana: An understory palm used as foliage in Colombia. Forest Ecology and Management 211: 329-340.

Rueff H, Parizot C, Israel A, Schwartz M (2008) Dryland afforestation and poverty alleviation: Bedouin and Palestinian non-timber forest product collectors in contrasting economic environments. Human Ecology 36: 923-930.

Ruiz-Pérez $M$ et al. (2008) Markets drive the specialization strategies of forest peoples. Ecology and Society 9: online.

Runk J, Mepaquito P, Pena F (2004) Artisanal non-timber forest products in Darien Province, Panama: The importance of context. Conservation \& Society 2: 217-234.

Russell-Smith J, Karunaratne NS, Mahindapala R (2006) Rapid inventory of wild medicinal plant populations in Sri Lanka. Biological Conservation 132: 22-32.

Saha D, Sundryiyal R (2012) Utilization of non-timber forest products in humid tropics: Implications for management and livelihood. Forest Policy and Economics 14: $28-40$.

Salick J, Zhengong F, Byg A (2009) Eastern Himalayan alpine plant ecology, Tibetan ethnobotany, and climate change. Global Environmental Change 19: 147-155.

Salisbury D, Schmink M (2007) Cows versus rubber: Changing livelihoods among Amazonian extractivists. Geoforum 38: 1233-1249.

Sampaio MB, Schmidt IB, Figueiredo IB (2008) Harvesting effects and population ecology of the buriti palm (Mauritia flexuosa L. f., Arecaceae) in the Jalapão Region, Central Brazil. Economic Botany 2: 171-181.

Sarmah R, Aruncachalam, A (2011) Contribution of non-timber forest products (NTFPS) to livelihood economy of the people living in forest fringes in Changlang District of Arunachal Pradesh, India. Indian Journal of Fundamental and Applied Life Sciences I: 157-160.

Schmidt IB, Figueiredo IB, Scariot A (2007) Ethnobotany and effects of harvesting on the population ecology of Syngonanthus nitens (Bong.) Ruhland (Eriocaulaceae), a NTFP from Jalapão region, central Brazil. Economic Botany 61: 73-85. 
Schreckenberg K, Degrande A, Mbosso C, Baboule Z, Boyd C, Enyong L, Kanmegne J Ngong C (2002) The social and economic importance of Dacryodes edulis (G.Don) H.J. Lam in Southern Cameroon. Forests, Trees and Livelihoods 12: 15-50.

Schroth G, Mota MSS, Lopes R, Freitas AF (2004) Extractive use, management and in situ domestication of a weedy palm, Astrocaryum tucuma, in the central Amazon. Forest Ecology and Management 202: 161-179.

Schumann K, Wittig R, Thiombiano A, Becker U, Hahn K (2010) Impact of land-use type and bark- and leaf-harvesting on population structure and fruit production of the baobab tree (Adansonia digitata L.) in a semi-arid savanna, West Africa. Forest Ecology and Management 260: 2035-2044.

Schwartzman S, Moreira A, Nepstad D (2000) Rethinking tropical forest conservation: Perils in the parks. Conservation Biology 14: 1351-1357.

Senarathne A, Abeygunawardena $P$, Jayatilake W (2003) Changing role of non-timber forest products (NTFP) in rural household economy: The case of Sinharaja World Heritage Site in Sri Lanka. Environmental Management 32: 559-571.

Shaanker RU, Ganeshaiah KN, Krishnani S, Ramya R, Meera C, Aravind NA, Kumar A, Rao D, Vanaraj G, Ramachandra J, Gauthier R, Ghazoul J, Poole N, Reddy BVC (2004) Livelihood gains and ecological costs of non-timber forest product dependence: Assessing the roles of dependence, ecological knowledge and market structure in three contrasting human and ecological settings in south India. Environmental Conservation 31: 242-253.

Shaanker RU, Ganeshaiah KN, Rao MN, Aravind NA (2004) Ecological consequences of forest use: From genes to ecosystem- A case study in the Biligiri Rangaswamy Temple Wildlife Sanctuary, South India. Conservation \& Society 2: 347-363.

Shackleton C, Guthrie G, Main R (2005) Estimating the potential role of commercial over-harvesting in resource viability: A case study of five useful tree species in South Africa. Land Degradation \& Development 16: 273-286.

Shackleton C, Shackleton S, Buiten E, Bird N (2007) The importance of dry woodlands and forests in rural livelihoods and poverty alleviation in South Africa. Forest Policy and Economics 9: 558-577.

Shackleton C, Timmermans H, Nongwe N, Hamer N, Palmer N (2007) Direct-use values of non-timber forest products from two areas on the Transkei Wild Coast. Agrekon 46: 135-156.

Shackleton C, Parkin F, Chauke MI, Downsborough L, Olsen A, Brill G, Weideman C (2009) Conservation, commercialization and confusion: Harvesting of Ischyrolepis in a coastal forest, South Africa. Environment, Development and Sustainability 11: 229-240.

Shackleton S, Delang C, Angelsen A (2011) From subsistence to safety nets and cash income: Exploring the diverse values of non-timber forest products for livelihoods and poverty alleviation. In: Shackleton S, Shackleton C, Shanley P (eds) Non-timber forest products in the global context. Tropical Forestry 7 ed. SpringerVerlag, London, UK pp. 55-81.

Shackleton C, Delang C, Shackleton S, Shanley P (2011) Non-timber forest products: Concept and definitions. In: Shackleton S, Shackleton C, Shanley P (eds) Non- 
timber forest products in the global context. Tropical Forestry 7 ed. Springer-Verlag, London, UK pp. 3-21.

Sheil D, Wunder S (2002) The value of tropical forest to local communities: Complications, caveats, and cautions. Conservation Ecology 6: online.

Shylajan C, Mythili G (2003) Community dependence on protected forest areas: A study on valuation of non-wood forest products in a region of India. Sri Lankan Journal of Agricultural Economics 5: 97-122.

Siebert SF (2000) Abundance and growth of Desmoncus orthacanthus Mart. (Palmae) in response to light and ramet harvesting in five forest sites in Belize. Forest Ecology and Management 137: 83-90.

Siebert SF (2001) Tree cutting to float rattan to market: A threat to primary forests? Journal of Bamboo and Rattan 1: 37-42.

Siebert SF (2004) Demographic effects of collecting rattan cane and their implications for sustainable harvesting. Conservation Biology 18: 424-431.

Sinha A, Bawa KS (2002) Harvesting techniques, hemiparasites and fruit production

in two non-timber forest tree species in south India. Forest Ecology and Management 168: 289-300.

Southgate D, Coles-Ritchie M, Salazar-Canelos $P$ (1995) Can tropical forests be saved by harvesting non-timber products? CSERGE Working Paper GEC 96-02.

Stave J, Oba J, Stenseth NC (2001) Temporal changes in woody-plant use and the ekwar indigenous tree management system along the Turkwel River, Kenya. Environmental Conservation 28: 150-15.

Stewart K (2009) Effects of bark harvest and other human activity on populations of the African cherry (Prunus africana) on Mount Oku, Cameroon. Forest Ecology and Management 258: 1121-1128.

Stoian D (2005) Making the best of two worlds: Rural and peri-urban livelihood options sustained by nontimber forest products from the Bolivian Amazon. World Development 33: 1473-1490.

Straede S, Nebel G, Rijal A (2002) Structure and floristic composition of community forests and their compatibility with villagers' traditional needs for forest products. Biodiversity and Conservation 11: 487-508.

Summers P, Browder J, Pedlowski M (2004) Tropical forest management and silvicultural practices by small farmers in the Brazilian Amazon: Recent farmlevel evidence from Rondonia. Forest Ecology and Management 192: 161-177.

Sunderlin WD, Dewi S, Puntodewo A, Angelsen A, Epprecht M (2008) Why forests are important for global poverty alleviation: A spatial explanation. Ecology and Society 13: 24 (online).

Svenning JC, Macía MJ (2002) Harvesting of Geonoma macrostachys Mart. leaves for thatch: An exploration of sustainability. Forest Ecology and Management 167: 251262.

Sylvester O, Avalos G (2009) Illegal palm heart (Geonoma edulis) harvest in Costa Rican National Parks: Patterns of consumption and extraction. Economic Botany 63: 179-189.

Tabuti J, Dhillion S, Lye K (2003) Firewood use in Bulamogi County, Uganda: Species selection, harvesting and consumption patterns. Biomass and Bioenergy 25: 581596. 
Takasaki Y, Barham B, Coomes O (2004) Risk coping strategies in tropical forests: Floods, illnesses, and resource extraction. Environment and Development Economics 9: 203-224.

Thapa S, Chapman DS (2010) Impacts of resource extraction on forest structure and diversity in Bardia National Park, Nepal. Forest Ecology and Management 259: 641-649.

Tewari D (2000) Managing non-timber forest products (NTFPs) as an economic resource. Journal of Interdisciplinary Economics 11: 269-287.

Ticktin $T$ (2004) The ecological implications of harvesting non-timber forest products. Journal of Applied Ecology 41: 11-21.

Ticktin T, Nantel P (2004) Dynamics of harvested populations of the tropical understory herb Aechmea magdalenae in old-growth versus secondary forests. Biological Conservation 120: 461-470.

Ticktin T (2005) Applying a metapopulation framework to the management and conservation of a non-timber forest species. Forest Ecology and Management 206: 249-261.

Ticktin T, Whitehead AN, Fraiola $\mathrm{H}$ (2006) Traditional gathering of native hula plants in alien-invaded Hawaiian forests: Adaptive practices, impacts on alien invasive species and conservation implications. Environmental Conservation 33: 185-194.

Ticktin T, Fraiola $\mathrm{H}$, Whitehead AN (2007) Non-timber forest product harvesting in alien-dominated forests: Effects of frond-harvest and rainfall on the demography of two native Hawaiian ferns. Plant Conservation and Biodiversity 16: 1633-1651.

Trivedi M, Cornejo FH, Watkinson AR (2004) Seed predation on Brazil nuts (Bertholletia excelsa) by macaws (Psittacidae) in Madre de Dios, Peru. Biotropica 36: 118-122.

Twine W, Moshe D, Netshiluvhi T, Siphrugu V (2003) Consumption and direct-use values of savanna bio-resources used by rural households in Mametja. South African Journal of Science 99: 467-479.

United Nations General Assembly (March 20, 1987). Report of the World Commission on Environment and Development: Our Common Future; Transmitted to the General Assembly as an Annex to document A/42/427 - Development and International Co-operation: Environment; Our Common Future, Chapter 2: Towards Sustainable Development; Paragraph 1 United Nations General Assembly. Retrieved from http://www.un-documents.net/ocf-02.htm 1 March 2010.

Vazquez-Lopez JM, Vibrans H, García-Moya E, Valdez-Hernández JI, RomeroManzanares A, Cuevas-Guzmán R (2004) Effects of harvesting on the structure of a neotropical woody bamboo (Otatea: Guaduinae) populations. Interciencia 29: 207-211.

Vedeld P, Angelsen A, Bojo J, Sjaastad E, Berg G (2007) Forest environmental incomes and the rural poor. Forest Policy and Economics 9: 869-879.

Vedeld P, Angelsen A, Sjaastad E, Berg G (2004) Counting on the environment: Forest incomes and the rural poor. In: Environmental Economics Series, World Bank, Washington, DC, paper No. 98.

Voeks RA (1996). Extraction and tropical rain forest conservation in eastern Brazil. In: Edwards D, Booth W, Choy S (eds) Tropical rainforest research: Current issues. Kluwer Acad. Publ, Netherlands, pp.477-487. 
Voeks, RA (2002) Reproductive ecology of the piassava palm (Attalea funifera Mart.) of Bahia, Brazil. Journal of Tropical Ecology 18: 121-136.

Voeks R A (2011) Ethnobotany. Chapter 26. In: The Sage Handbook of Biogeography. A. Millington, M. Blumler, G. MacDonald, and U. Schickhoff (eds). Los Angeles, CA: Sage Publications, pp. 493-509.

Vormisto J (2002) Palms as rainforest resources: How evenly are they distributed in Peruvian Amazonia? Biodiversity and Conservation 11: 1025-1045.

Wadt LHO, Kainer KA, Staudhammer CL, Serrano ROP (2008) Sustainable forest use in Brazilian extractive reserves: Natural regeneration of Brazil nut in exploited populations. Biological Conservation 141: 332-346.

Weinstein S, Moegenburg S (2004) Açaí palm management in the Amazon estuary: Course for conservation or passage to plantations? Conservation \& Society 2: 315-346.

Wilkie D, Clark L, Godoy R (2001) NTFPs: Economic and conservation potential in Central Africa. European Tropical Forest Research Network newsletter 32: 32-34.

Wolf J, Flamenco-S A (2006) Vascular epiphytes and their potential as a conservation tool in pine-oak forests of Chiapas, Mexico. Ecological Studies 185: 375-391.

Wollenberg E (2001) Incentives for collecting gaharu (fungal-infected wood) in East Kalimantan. Economic Botany 55: 444-456.

Yang X, Wikes A, Yang Y, Xu J, Geslani C, Yang X, Goa F, Yang J, Robinson B (2009) Common and privatized: Conditions for wise management of Matsutake mushrooms in Northwest Yunnan Province, China. Ecology and Sociology 14: 2930.

Zimmerman B, Peres CA, Malcolm JR, Turner T (2001) Conservation and development alliances with the Kayapó of south-eastern Amazonia, a tropical forest indigenous people. Environmental Conservation 28: 10-22.

Zuidema PA, Boot RGA (2000) Demographic constraints to sustainable palm heart extraction from a sub-canopy palm in Bolivia. In: Zuidema PA. Demography of Exploited Tree Species in the Bolivian Amazon. Universit Utrecht, Promab, pp. 53-80.

Zuidema PA, Boot RGA (2002) Demography of the Brazil nut tree (Bertholletia excelsa) in the Bolivian Amazon: Impact of seed extraction on recruitment and population dynamics. Journal of Tropical Ecology 18: 1-31.

Zuidema PA, Kroon H, Werger MJA (2007) Testing sustainability by prospective and retrospective demographic analysis: Evaluation for palm leaf harvest. Ecological Applications 17:118-128. 
Appendix 1: Creation of Economic Sustainability Thresholds

We use the following steps to assess economic sustainability:

a) take the study-reported (usually household and/or yearly) reported values from NTFP gathering (both cash income and use), usually presented in local currency;

b) convert those values to a $\$$ figure using a current exchange rate and a PPP conversion factor;

c) use information regarding household size to convert to the "adjusted scale size" of household members;

d) define an appropriate alternative wage to gathering;

e) calculate the total, scale-adjusted, per-person PPP\$ value from NTFPs at a periodlevel (usually yearly); calculation of the number of "non-poverty days" this value would cover, if each day requires $\$ 2$ PPP/day;

f) calculate the total household current $\$$ value from NTFPs at a period-level; calculation of the number of "attractive days" this value would cover, if each day requires meeting the alternative local wage;

g) compare the reported days (if available) to the criteria in e) and f).

Each included study reports some form of value from extraction at the household (or individual) yearly (or daily, monthly) level. Our goal is to compare all studies on a daily basis of \$ PPP per person (scaled) and on a daily basis of returns (\$ current rate) against a local wage. If the study authors report the values from gathering across sub-samples of a population (i.e. for each of 3 villages), we reported the sample-weighted mean of returns in Table 2. Steps are still needed to convert dollars, on a per-person basis, and against a threshold.

Currency conversion issues (step 2) have been dealt with in many of the included studies. Over $50 \%$ report an accepted current exchange rate accepted at the time and place of the study. However, for consistency, we choose to work with a common source PPP-adjusted exchange rates. The World Bank's World Development Indicators database allows us to find what was the current level GDP in local and \$ values for that year, as well as a PPP-adjusted GDP total for a PPP-adjustment factor to convert local currency to a level consistent with consumption standards. [Most developing countries in the sample required a 1.2-4 PPP adjustment on GDP.]

For (c) we should convert the total reported income to values in adult equivalents, which offers a more realistic measure of household consumption instead of per capita levels (Cavendish, 2004). However, while most studies report total household size they offer few details on demographic composition of the sample. So we work with Deaton's economies of scale measure (reported in Cavendish, 2004) to better compare consumption needs across households. [That is, a household of 10 people really has the consumption needs of 7.3 adults while those of 5 people require about 4.5.] ${ }^{1}$

Few studies give "time opportunity cost" data regarding the local wage rates for paid labor around the study site during the study year for step (d). So we also rely upon data from the ILO's Laborstat database (ILO, 2011). Here 42 developing countries provide

In studies in which absolutely no information was available on household size we extrapolate using the regional mean derived from the other studies. 
information on wage income by sector, usually on a monthly basis for all men and women in a labor survey. Over half of these countries provided the income for both workers in the manufacturing and the agricultural sectors. We are most interested in finding a daily agricultural wage rate for the NTFP study countries in the early part of the decade, around 2000. For this we convert all monthly individual wage incomes to a daily $\$$ wage rate and run an OLS regression to impute the probable agricultural wage rate for those countries with no data. ${ }^{2}$

\footnotetext{
${ }^{2}$ We find the current $\$ 1$ US exchange rate using the OANDA converter. We use this same converter for the conversion of the study findings and a within-country comparison. We convert the threshold survey monthly income to a daily rate by assuming 4.33 work weeks at 5 days each. Agricultural incomes are usually less than manufacturing incomes, with an OLS estimation as:

$\mathrm{W}_{\text {agric }}=1.46+0.486 \mathrm{~W}_{\text {manufacture }} \quad \mathrm{R}$-squared $=0.94 \quad \mathrm{~F}_{(1,21)}=166.86$ (0.93) (0.04)

Generally this provides levels of a "going daily wage" in the agricultural sector between $\$ 2.04$ per person (Honduras) to $\$ 12.86$ (Jamaica). Overall, however, these imputed daily agricultural wage rates appeared the lowest in the Asian developing countries compared to the Latin American region. This follows the general pattern of the earlier studies in Ruiz Perez, et al. (2004) in which the local labor rate varied from \$5.62 per day in Africa to $\$ 10.25$ per day in Latin America across the 1990s.
} 
Stanley et al. 2012. Is Non-Timber Forest Product Harvest Sustainable in the Less Developed World? A Systematic Review of the Recent Economic and Ecological Literature. Ethnobio Conserv 1:7

Appendix 2: Recent trends in the assessment of sustainability of non-timber forest products assessed by studies focusing on 1-2 species

\begin{tabular}{|c|c|c|c|c|c|c|c|c|c|c|c|}
\hline \multirow[b]{3}{*}{ Species, Genera, or Life Form } & \multirow[b]{3}{*}{ Region/Country } & \multirow{3}{*}{\multicolumn{2}{|c|}{$\begin{array}{l}\text { Ecological Concerns } \\
\text { Part harvested }\end{array}$}} & \multicolumn{8}{|c|}{ \# of studies } \\
\hline & & & & \multicolumn{4}{|c|}{ Level of focus } & \multicolumn{4}{|c|}{$\begin{array}{l}\text { Sustainability } \\
\text { assessment }\end{array}$} \\
\hline & & & & $\frac{\bar{\pi}}{\stackrel{0}{2}}$ & 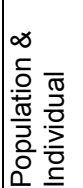 & 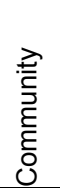 & 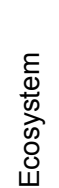 & $\begin{array}{l}\frac{0}{0} \\
\frac{0}{00} \\
. \frac{C}{10} \\
\frac{\pi}{01} \\
0 \\
0\end{array}$ & 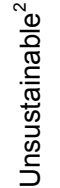 & $\begin{array}{l}\sum_{0}^{\infty} \\
\frac{1}{5} \\
\frac{5}{5} \\
\frac{5}{5}\end{array}$ & 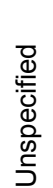 \\
\hline Adansonia digitata $\mathrm{L}$. & AFR (Mali, Burkina Faso) & $\mathrm{S}$ & $\begin{array}{l}\text { Fruit, seed, nut } \\
\text { Leaves, fronds, foliage } \\
\text { Bark }\end{array}$ & & 2 & & & 2 & & & \\
\hline $\begin{array}{l}\text { Aechmea magdalenae André ex } \\
\text { Baker }\end{array}$ & LA (Mexico) & TE & Leaves, fronds, foliage & & 2 & & & & & 2 & \\
\hline Agave marmorata Roezl & LA (Mexico) & TSE, H & $\begin{array}{l}\text { Flower, inflorescence } \\
\text { Leaves, fronds, foliage } \\
\text { Whole plant, heart, stem, meristem }\end{array}$ & & 1 & & & 1 & & & \\
\hline Aloe peglerae Schönland & AFR (South Africa) & $\mathrm{S}$ & $\begin{array}{l}\text { Fruit, seed, nut } \\
\text { Whole plant, heart, stem, meristem }\end{array}$ & & 1 & & & & 1 & & \\
\hline Aquilaria malaccensis Lam. & AS (Indonesia) & TE & Resin, pulp, woody portion** & & 1 & & & 1 & & & \\
\hline Astrocaryum tucuma Mart. & LA (Brazil) & TE & Fruit, seed, nut & & 1 & & & 1 & & & \\
\hline Bertholletia excels Bonpl. & LA (Bolivia, Brazil, Peru) & TE & $\begin{array}{l}\text { Fruit, seed, nut } \\
\text { Whole plant, heart, stem, meristem }\end{array}$ & & 4 & 2 & & 5 & 1 & & \\
\hline Calamus zollingeri Becc. & AS (Indonesia) & TE & Leaves, fronds, foliage & & 1 & & 1 & 1 & & 1 & \\
\hline Carapa procera DC. & $\begin{array}{l}\text { LA (Fr. Guiana \& } \\
\text { Suriname) }\end{array}$ & TE & Fruit, seed, nut & & & 1 & & 1 & & & \\
\hline Carapa surinamensis Miq. & LA (French Guiana) & TE & $\begin{array}{l}\text { Generic or unspecified } \\
\text { Whole plant, heart, stem, meristem }\end{array}$ & & & 1 & & 1 & & & \\
\hline Chamaedorea elegans Mart. & LA (Mexico, lab in USA) & $\mathrm{TE}$ & Leaves, fronds, foliage & 1 & 1 & & & 1 & & & 1 \\
\hline Chamaedorea radicalis Mart. & LA (Mexioo) & TE, ME & Leaves, fronds, foliage & 1 & 2 & 1 & & 3 & & 1 & \\
\hline Copaifera spp. & LA (Brazil) & TE & Resin, pulp, woody portion ${ }^{* *}$ & 1 & & & & & 1 & & \\
\hline Copaifera multijuga Hayne & LA (Brazil) & TE & Resin, pulp, woody portion ${ }^{\star *}$ & & & 1 & & 1 & & & \\
\hline Cyperus scariosus $\mathrm{R}$. Br. & AS (India) & TSE & Whole plant, heart, stem, meristem & 1 & & & & 1 & & & \\
\hline Desmoncus orthacanthos Mart. & LA (Belize, Mexico) & TE & Leaves, fronds, foliage & & 2 & & & 2 & & & \\
\hline $\begin{array}{l}\text { Dioon merolae De Luca, Sabato \& } \\
\text { Vázq.Torres }\end{array}$ & LA (Mexico) & TSE, TD* & Leaves, fronds, foliage & & 1 & & & 1 & & & \\
\hline Dioscorea spp. & AFR (Madagascar) & TSE, TD* & Root ,tuber, bulb, corm & & 1 & & & 1 & & & \\
\hline Eremospatha macrocarpa H. Wendl & AFR (Côte d'Ivoire) & TE & Leaves, fronds, foliage & & 1 & & & 1 & & & \\
\hline Euterpe edulis Mart. & LA (Brazil) & TE & Whole plant, heart, stem, meristem & & 1 & 2 & & 2 & 1 & & \\
\hline Euterpe oleracea Mart. & LA (Brazil) & TE & Fruit, seed, nut & & & 2 & & 2 & & & \\
\hline
\end{tabular}


Stanley et al. 2012. Is Non-Timber Forest Product Harvest Sustainable in the Less Developed World? A Systematic Review of the Recent Economic and Ecological Literature. Ethnobio Conserv 1:9

\begin{tabular}{|c|c|c|c|c|c|c|c|c|c|c|}
\hline & & & Whole plant, heart, stem, meristem & & & & & & & \\
\hline Euterpe precatoria Mart. & AS (Bolivia) & TE & Whole plant, heart, stem, meristem & & 1 & & & & 1 & \\
\hline Garcinia gummi-gutta (L). Roxb. & AS (India) & $\mathrm{TE}$ & Fruit, seed, nut & 1 & & & & 1 & & \\
\hline Garcinia lucida Vesque & AFR (Cameroon) & $\mathrm{TE}$ & $\begin{array}{l}\text { Fruit, seed, nut } \\
\text { Bark } \\
\text { Branch } \\
\end{array}$ & & 2 & & & 2 & & \\
\hline Geonoma deversa (Poit.) Kunth & LA (Bolivia) & $\mathrm{TE}$ & Leaves, fronds, foliage & & 1 & & & 1 & & \\
\hline $\begin{array}{l}\text { Geonoma edulis H. Wendl. Ex } \\
\text { Spruce }\end{array}$ & LA (Costa Rica) & $\mathrm{ME}$ & Whole plant, heart, stem, meristem & & 1 & & & & 1 & \\
\hline Geonoma macrostachys Mart. & LA (Ecuador) & TE & Leaves, fronds, foliage & & 1 & & & 1 & & \\
\hline Geonoma orbignyana Mart. & LA (Colombia) & TE & Leaves, fronds, foliage & & 1 & & & 1 & & \\
\hline $\begin{array}{l}\text { Heteropsis flexuosa (Kunth) G.S. } \\
\text { Bunting }\end{array}$ & LA (Brazil) & $\mathrm{TE}$ & Root ,tuber, bulb, corm & & 1 & & & 1 & & \\
\hline Iriartea deltoidea Ruiz \& Pav. & LA (Ecuador) & TE & Leaves, fronds, foliage & & 1 & & & 1 & & \\
\hline $\begin{array}{l}\text { Ischnosiphon polyphyllus (Poepp.\& } \\
\text { Endl.) Körn }\end{array}$ & LA (Brazil) & TE & Whole plant, heart, stem, meristem & & 1 & & & & 1 & \\
\hline $\begin{array}{l}\text { Ischyrolepis eleocharis (Nees ex } \\
\text { Mast.) H.P.Linde }\end{array}$ & AFR (South Africa) & CD & Whole plant, heart, stem, meristem & & 1 & & & 1 & & \\
\hline Khaya senegalensis (Desv.) A.Juss. & AFR (Benin) & $\mathrm{S}$ & $\begin{array}{l}\text { Leaves, fronds, foliage } \\
\text { Bark } \\
\text { Branch }\end{array}$ & & 3 & 1 & & 2 & & 2 \\
\hline $\begin{array}{l}\text { Laccosperma secundiflorum } \\
\text { (P.Beauv.) Kuntze }\end{array}$ & AFR (Côte d'Ivoire) & TE & $\begin{array}{l}\text { Leaves, fronds, foliage } \\
\text { Leaves, fronds, foliage }\end{array}$ & & 1 & & 1 & 2 & & \\
\hline Lychnophora ericoides Mart. & LA (Brazil) & $S$ & Leaves, fronds, foliage & & & & 1 & 1 & & \\
\hline Mauritia flexuosa L.f. & LA (Brazil, Ecuador) & TE & $\begin{array}{l}\text { Fruit, seed, nut } \\
\text { Leaves, fronds, foliage }\end{array}$ & & 2 & & & 2 & & \\
\hline Microlepia strigosa (Thunb.) C. Presl & AS (U.S.A.-Hawaii) & TE & Leaves, fronds, foliage & & 1 & & & 1 & & \\
\hline Nardostachys grandiflora DC. & AS (Nepal) & AM & $\begin{array}{l}\text { Root ,tuber, bulb, corm } \\
\text { Leaves, fronds, foliage } \\
\text { Whole plant, heart, stem, meristem }\end{array}$ & & 1 & & & & & 1 \\
\hline Otatea spp. & LA (Mexico) & TE & Whole plant, heart, stem, meristem & & 1 & & & 1 & & \\
\hline Pentadesma butyracea Sabine & AFR (Benin) & TE & Fruit, seed, nut & & 1 & & & & & 1 \\
\hline Phyllanthus emblica L. & AS (India) & $\mathrm{TD}, \mathrm{H}$ & Fruit, seed, nut & & & 1 & & & 1 & \\
\hline Phyllanthus indofischeri Bennet & AS (India) & $\mathrm{TD}, \mathrm{H}$ & Fruit, seed, nut & & & 1 & & & 1 & \\
\hline Prunus Africana (Hook f.) Kalkman & AFR (Cameroon) & ME & Bark & & 1 & & & 1 & & \\
\hline $\begin{array}{l}\text { Rumohra adiantiformis (G. Forst.) } \\
\text { Ching }\end{array}$ & LA (Brazil) & $\mathrm{TE}$ & Leaves, fronds, foliage & & 1 & & & & & 1 \\
\hline $\begin{array}{l}\text { Sclerocaryabirrea subsp. caffra } \\
\text { (Sond.) Kokwaro }\end{array}$ & AFR (South Africa) & TD & Fruit, seed, nut & & 1 & & & 1 & & \\
\hline Sphenomeris chinensis (L.) Maxon & AS (U.S.A.-Hawaii) & TE & Leaves, fronds, foliage & & 1 & & & 1 & & \\
\hline $\begin{array}{l}\text { Syngonanthus nitens (Bong.) } \\
\text { Ruhland }\end{array}$ & LA (Brazil) & $\mathrm{S}$ & $\begin{array}{l}\text { Flower, inflorescence } \\
\text { Leaves, fronds, foliage }\end{array}$ & & 1 & & & 1 & & \\
\hline
\end{tabular}


Stanley et al. 2012. Is Non-Timber Forest Product Harvest Sustainable in the Less Developed World? A Systematic Review of the Recent Economic and Ecological Literature. Ethnobio Conserv 1:9

\begin{tabular}{|c|c|c|c|c|c|c|c|c|c|c|c|}
\hline & & & Whole plant, heart, stem, meristem & & & & & & & & \\
\hline Ternstroemia lineate DC. & LA (Mexico) & ME & $\begin{array}{l}\text { Flower, inflorescence } \\
\text { Fruit, seed, nut }\end{array}$ & & 1 & & & 1 & & & \\
\hline $\begin{array}{l}\text { Thrinax radiate Lodd. ex Schult. \& } \\
\text { Schult.f. }\end{array}$ & LA (Mexico) & TSE, TD* & $\begin{array}{l}\text { Leaves, fronds, foliage } \\
\text { Root ,tuber, bulb, corm }\end{array}$ & 1 & & & & 1 & & & \\
\hline Epiphyte & LA (Mexico) & TSE, TD* & Whole plant, heart, stem, meristem & & & 1 & & 1 & & & \\
\hline Palm & LA (Brazil, Ecuador, Peru) & TE & $\begin{array}{l}\text { Leaves, fronds, foliage } \\
\text { Generic }\end{array}$ & & 2 & 1 & & 1 & 1 & & 1 \\
\hline Tree & $\begin{array}{l}\text { AFR (Benin, Kenya, } \\
\text { Nigeria, South Africa, } \\
\text { Tanzania, Uganda, } \\
\text { Zimbabwe) } \\
\text { AS (India, Nepal) }\end{array}$ & $\begin{array}{l}\text { TE, TSE, TD, } \\
\text { ME, H }\end{array}$ & $\begin{array}{l}\text { Fruit, seed, nut } \\
\text { Leaves, fronds, foliage } \\
\text { Root ,tuber, bulb, corm } \\
\text { Bark } \\
\text { Resin, pulp, woody portion** } \\
\text { Branch } \\
\text { Whole plant, heart, stem, meristem } \\
\text { Generic }\end{array}$ & 2 & 4 & 3 & 3 & 5 & 3 & 2 & 2 \\
\hline Palm and Fern & AS (U.S.A.-Hawaii) & TE & Leaves, fronds, foliage & & & 1 & & 1 & & & \\
\hline Shrub and Herb & AS (Nepal) & AM & Generic & & 1 & & & 1 & & & \\
\hline Tree and Herb & AS (India) & TE & Generic & & & & 1 & & & 1 & \\
\hline Tree and Palm & LA (Panama) & TE & $\begin{array}{l}\text { Fruit, seed, nut } \\
\text { Leaves, fronds, foliage } \\
\text { Resin, pulp, woody portion** }\end{array}$ & & 1 & & & 1 & & & \\
\hline Tree, Shrub, and Liana & AS (India) & TSE, TD* & $\begin{array}{l}\text { Branch } \\
\text { Whole plant, heart, stem, meristem }\end{array}$ & & & 1 & & & 1 & & \\
\hline Tree, Shrub, and Herb & AS (India) & TE & Whole plant, heart, stem, meristem & & & & 1 & & 1 & & \\
\hline Tree, Palm, Herb, and Bryophyte & AS (India) & TD & Generic & & & & 1 & 1 & & & \\
\hline Tree, Shrub, Liana, and Herb & AS (Sri Lanka) & TE, TSE, H, S & Generic & & & & 1 & & & 1 & \\
\hline Tree, Shrub, Herb, and Bryophyte & AS (Nepal) & TSE & $\begin{array}{l}\text { Fruit, seed, nut } \\
\text { Leaves, fronds, foliage } \\
\text { Root ,tuber, bulb, corm } \\
\text { Whole plant, heart, stem, meristem }\end{array}$ & & & 1 & & & 1 & & \\
\hline $\begin{array}{l}\text { Tree, Shrub, Herb, Liana, and } \\
\text { Bryophyte }\end{array}$ & AS (India) & ME & Generic & & & 1 & & 1 & & & \\
\hline $\begin{array}{l}\text { Tree, Shrub, Palm, Liana, Fern, and } \\
\text { Herb }\end{array}$ & AFR (Uganda) & TE, ME & Generic & & & 1 & & 1 & & & \\
\hline $\begin{array}{l}\text { Tree, Shrub, Palm, Herb, Liana, and } \\
\text { Epiphyte }\end{array}$ & LA (Panama) & TE & $\begin{array}{l}\text { Fruit, seed, nut } \\
\text { Leaves, fronds, foliage } \\
\text { Bark } \\
\text { Resin, pulp, woody portion** }\end{array}$ & & 1 & & & & & & 1 \\
\hline Generic, unspecified & & & & & & 2 & 2 & 3 & 1 & & \\
\hline
\end{tabular}


Legend: Sustainability assessment - ${ }^{1}$ Sustainable or suitable for sustainable extraction or management; ${ }^{2}$ Unsustainable or predicts unsustainable at high level; ${ }^{3}$ Unknown or both sustainable and unsustainable, depending on future actions. Regions - LA: Latin America; AS: Asia; AFR: Africa; (country of ecological studies). Environments of ecological studies - TE: tropical evergreen; TSE: tropical semi-evergreen; TD: tropical deciduous; ME: montane evergreen; $\mathrm{H}$ : healthland, shrubland, cactus or Joshua tree forest; S: savanna, cerrado; CD: coastal dune; AM: alpine meadow. *Those stated as tropical dry forests are cross-classified as "TSE, TD"; **Woody refers to NTFPs derived from modified, decomposed, or pulpy woody parts such as gaharu.

Note: Bryophyte category also includes mosses and lichens and other non-vascular plants, and mushrooms

Sources: Ackermann 2004; Amusa et al. 2010; Anderson and Putz 2002; Anten et al. 2003; Arjunan et al. 2005, Avocèvou-Ayisso et al. 2009; Baldauf and Dos Reis 2010; Bhat et al. 2003; Calvo-Irabién et al. 2009; Chhetri and Gupta 2006; Dalle and Potvin 2004; Datta et al. 2010; Andrade and Hay 2007; Delvaux et al. 2009, 2010; Dhillon and Gustad 2004; Reis et al. 2000; Emanuel et al. 2005; Endress 2004; Endress et al. 2004, 2004, 2006; Escalante et al. 2004; Escobal 2003; Fantini and Guries 2007; Forget and Jansen 2007; Gaoue and Ticktin 2007, 2008, 2009, 2010; Guariguata et al. 2009; Guedje et al. 2003, 2007; Holm et al. 2008; Jiménez-Valdés et al. 2010; Jones and Gorchov 2000; Karanth et al. 2006; Kouassi et al. 2008; Laresen 2002; Lázaro-Zermeño et al. 2010; Lermyte and Forget 2009; Marshall and Newton 2003; Martínez-Ramos et al. 2009; Matos and Bovi 2002; Medeiros and Vieira 2008; Menton 2003; Mishra et al. 2010; Misra and Dash 2000; Moegenburg and Levey 2002; Mukwada 2009; Mutenje et al. 2010; Meyers et al. 2000; Nakazono et al. 2004; Ndangalasi et al. 2007; Olupot et al. 2009; Omeja et al. 2004; Pandit and Thapa 2003; Paoli et al. 2001; Pedersen and Skov 2001; Peres et al. 2003; Pfab and Scholes 2004; Plowden 2003; Plowden et al. 2003; Portela et al. 2010; Rai and Uhl 2004; Rani et al. 2009; Robinson and Lokina 2010; Rodríguez-Buriticá et al. 2005; Runk et al. 2004; Russell-Smith et al. 2006; Sampaio et al. 2008; Schmidt et al. 2007; Schroth et al. 2004; Schumann et al. 2010; Shaanker et al. 2004, 2004; Shackleton et al. 2005, 2009; Siebert 2000, 2001, 2004; Sinha and Bawa 2002; Stave and Stenseth 2001; Stewart 2009; Straede et al. 2002; Svenning and Macía 2002; Sylvester and Avalos 2009; Thapa and Chapman 2010; Ticktin 2004, 2005; Ticktin and Nantel 2004; Ticktin et al 2006, 2007; Trivedi et al. 2004; Vazquez-Lopez et al. 2004; Vormisto 2002; Wadt et al. 2008; Weinstein and Moegenburg 2004; Wolf and Flamenco-S 2006; Zimmerman et al. 2001; Zuidema and Boot 2000, 2002; Zuidema et al. 2007 
Stanley et al. 2012. Is Non-Timber Forest Product Harvest Sustainable in the Less Developed World? A Systematic Review of the Recent Economic and Ecological Literature. Ethnobio Conserv 1:9

Appendix 3: Recent trends in the economic assessment of non-timber forest product sustainability.

\begin{tabular}{|c|c|c|c|c|c|c|c|}
\hline \multicolumn{2}{|l|}{ Identifier } & \multicolumn{6}{|c|}{ Economic Concerns } \\
\hline $\begin{array}{l}\text { Main Species, Genus, or Life } \\
\text { Form (if in a bundle) }\end{array}$ & Country & 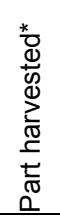 & Measurement & $\begin{array}{l}\text { Value given bundle } \\
\text { (local currency or } \$ \text { ) }\end{array}$ & $\begin{array}{l}N \\
\infty \\
\Lambda \\
\stackrel{\Lambda}{0} \\
\stackrel{\infty}{0} 0 \\
\stackrel{0}{0} \\
\stackrel{0}{0}\end{array}$ & $\begin{array}{l}0 \\
8 \\
\mathbb{8} \\
3 \\
\pi \\
0 \\
0 \\
\hat{0} \\
\stackrel{0}{0}\end{array}$ & Given Days \\
\hline Acacia rehmanniana Schinz & $\begin{array}{l}\text { South } \\
\text { Africa }\end{array}$ & 3 & HH gross direct use value/yr. & $\begin{array}{l}4559 \text { Rand user } \\
\text { households }\end{array}$ & $<139$ & & \\
\hline Agathis philippinensis Warb. & Philippines & 5 & $\begin{array}{l}\text { Daily income in collecting season } \\
\text { 4days/mo. }\end{array}$ & $170 \mathrm{PhP} \$ 3.12$ per day & any & & $\begin{array}{l}\text { January-March season, } \\
\text { about } 15 \text { days }\end{array}$ \\
\hline Aquilaria malaccensis Lam. & Borneo & 5 & $\begin{array}{l}\text { revenue and Net income/hh/yr.; } \\
\text { also per person day }\end{array}$ & $\begin{array}{l}1014000 \text { rps. gross; } \\
26,000 \\
\text { returns/person/day }\end{array}$ & $<465$ & 81 & 29 days gathering/HH \\
\hline Aquilaria malaccensis Lam. & Indonesia & 5 & $\begin{array}{l}\text { Annual gross financial } \\
\text { return/gatherer/day }\end{array}$ & $\$ 8.80$ & $<10$ & & $\begin{array}{l}\text { up to } 140 \text { days/yr. as } 14- \\
\text { day trip } 10 \text { times }\end{array}$ \\
\hline $\begin{array}{l}\text { Aquilaria crassna Pierre ex } \\
\text { Lecomte }\end{array}$ & Laos & 5 & Average net revenue/day & $\begin{array}{l}73,735 \text { kip } \$ 7 ; \text { varies } \\
\$ 4-\$ 13 / \text { day by locality }\end{array}$ & & & $\begin{array}{l}\text { average } 92.25 \text { collection } \\
\text { days, } 8.77 \text { trips }\end{array}$ \\
\hline Asparagus racemosus Willd. & Nepal & 8 & Income/hh/yr. & $8820 \mathrm{NRs}$ & $<45$ & 50 & \\
\hline $\begin{array}{l}\text { Attalea phalerata Mart. ex } \\
\text { Spreng. }\end{array}$ & Bolivia & 2 & $\begin{array}{l}\text { Mean value HH consumption; } \\
\text { mean cash earnings }\end{array}$ & $\$ 199-\$ 337 ; \$ 28-\$ 108$ & $<109$ & & $\begin{array}{l}\text { sampled days to } \\
\text { extrapolate year }\end{array}$ \\
\hline Bambusa tulda Roxb. & Thailand & 8 & $\begin{array}{l}\text { Time value/hh/yr. of consumption } \\
\text { products }\end{array}$ & $\begin{array}{l}\$ 30.86 ; \$ 302 \text {. substitute } \\
\text { value }\end{array}$ & $<89$ & 66 & 14.63 days/ yr./HH \\
\hline Bertholletia excelsa Bonpl. & Peru & 2 & Income/hh/yr. & $\$ 3778-\$ 3918$ & $<853$ & & 3 months time, so 65 days \\
\hline $\begin{array}{l}\text { Boletus pinophilus Pilát \& } \\
\text { Dermek }\end{array}$ & Mexico & 8 & $\begin{array}{l}\text { Value of cash income/ } \\
\text { household/day for } 3 \text { months/yr. }\end{array}$ & $62.5 \mathrm{MX}$ pesos & $<11$ & & \\
\hline Calamus spp. & Philippines & 5 & $\begin{array}{l}\text { Daily income in collecting season } \\
\text { 4days/mo. }\end{array}$ & 170 PhP \$3.12 per day & any & & $\begin{array}{l}\text { January-March season, } \\
\text { about } 15 \text { days }\end{array}$ \\
\hline Centella asiatica (L.) Urb. & Bangladesh & 7 & Consumption value/hh/month & I TK 594 & $<30$ & & \\
\hline
\end{tabular}


Stanley et al. 2012. Is Non-Timber Forest Product Harvest Sustainable in the Less Developed World? A Systematic Review of the Recent Economic and Ecological Literature. Ethnobio Conserv 1:9

\begin{tabular}{|c|c|c|c|c|c|c|c|}
\hline Chamaedorea spp. & Mexico & 3 & $\begin{array}{l}\text { Net income (cash \& use-purchased } \\
\text { inputs) per capita/yr. }\end{array}$ & 820 pesos & $<63$ & & \\
\hline $\begin{array}{l}\text { Cinnamomum tamala (Buch.- } \\
\text { Ham.) T.Nees \& Eberm. }\end{array}$ & Nepal & 4 & Revenue/hh/yr & 3148 NRs & $<15$ & 35 & \\
\hline Dalichini [common name] & Nepal & 3 & Revenue/hh/yr & 17767 NRs & $<94$ & 104 & \\
\hline $\begin{array}{l}\text { Dipterocarpus alatus Roxb. } \\
\text { Ex G.Don }\end{array}$ & Cambodia & 5 & gross income/collector/year & $\begin{array}{l}\text { \$58.5 all plant-based } \\
\text { NTFPs }\end{array}$ & $<88$ & 20.3 & \\
\hline Euterpe oleracea Mart. & Brazil & 2 & est. gross income/hh/yr & $\$ 70-\$ 8100$ & $<740$ & 520 & $\begin{array}{l}\text { most in summer season } \\
\text { June-Dec. for } 152 \text { days }\end{array}$ \\
\hline Euterpe precatoria Mart. & Bolivia & 2 & Gross income/person/yr. & $\begin{array}{l}3634 \text { Bolivians Brazil } \\
\text { nut; } 3948 \text { all products }\end{array}$ & $<900$ & & $\begin{array}{l}\text { few months gathering ( } 3 \\
\text { men, } 1 \text { women); so } 65 \\
\text { days men }\end{array}$ \\
\hline Euterpe precatoria Mart. & Peru & 2 & Income/hh/yr. as 14 months & $\begin{array}{l}\text { \$1224/hh; about } \\
\$ 552 / \text { participant }\end{array}$ & $<457$ & & $\begin{array}{l}6 \text { months total, so } 130 \\
\text { days }\end{array}$ \\
\hline $\begin{array}{l}\text { Garcinia gummi-gutta (L.) } \\
\text { Roxb. }\end{array}$ & India & 2 & $\begin{array}{l}\text { Annual per household cash } \\
\text { income }\end{array}$ & 10792 Rps. & $<91$ & 115 & up to 66 days season \\
\hline Gevuina avellana Molina & Chile & 7 & $\begin{array}{l}\text { Gross financial returns/collector/3- } \\
5 \text { hrs. in yr. }\end{array}$ & $\begin{array}{l}\text { Romerillo } \$ 5.6 \text {, } \\
\text { Avellana } \$ 8.1\end{array}$ & $<11$ & Any & \\
\hline Gnetum africanum Welw. & Nigeria & 2 & Individual mean annual income & 19,977 NGN & $<131$ & & $\begin{array}{l}\text { seasonal 3-5 months; } 108 \\
\text { days }\end{array}$ \\
\hline Lacosperma sp. & Cameroon & 6,8 & Net income per AEU & 10,500 CFA & 102 days & $\begin{array}{l}\text { OC } \\
\text { labor } \\
\text { already } \\
\text { included }\end{array}$ & \\
\hline Lomatia ferruginea R. Br. & Chile & 7 & $\begin{array}{l}\text { Gross financial returns/collector/3- } \\
5 \text { hrs. in yr. }\end{array}$ & $\begin{array}{l}\text { Romerillo } \$ 5.6 \text {, } \\
\text { Avellana } \$ 8.1\end{array}$ & $<11$ & Any & \\
\hline Mauritia flexuosa L. f. & Peru & 2,3 & $\begin{array}{l}\text { Revenue (use+sale)/hh/year } \\
\text { Total income (use, } \\
\text { sale)/hh/yr.;mean daily income }\end{array}$ & $\begin{array}{l}\text { \$1658, \$376 no game } \\
\$ 1374 / \mathrm{hh} \text { total }\end{array}$ & $\begin{array}{l}<879 \\
<4.5\end{array}$ & & \\
\hline
\end{tabular}


Stanley et al. 2012. Is Non-Timber Forest Product Harvest Sustainable in the Less Developed World? A Systematic Review of the Recent Economic and Ecological Literature. Ethnobio Conserv 1:9

\begin{tabular}{|c|c|c|c|c|c|c|c|}
\hline & & & $\begin{array}{l}\text { extraction } \\
\text { Income/hh/yr. as } 14 \text { months }\end{array}$ & $\begin{array}{l}\$ 1224 / \mathrm{hh} ; \text { about } \\
\$ 552 / \text { participant }\end{array}$ & $<457$ & & $\begin{array}{l}6 \text { months total, so } 130 \\
\text { days }\end{array}$ \\
\hline $\begin{array}{l}\text { Ophiocordyceps sinensis } \\
\text { (Berk.) G.H. Sung, J.M. } \\
\text { Sung, Hywel-Jones \& } \\
\text { Spatafora }\end{array}$ & China & 8 & Household sales income per year & $\begin{array}{l}2200 \text { CNY mushrooms; } \\
350 \text { CNY medicinal } \\
\text { plants }\end{array}$ & $<83$ & 78 & 44 days in season \\
\hline Phyllanthus emblica L. & India & 2 & $\begin{array}{l}\text { gross income sales + } \\
\text { consumption/hh/yr }\end{array}$ & $3583 \mathrm{Rps} . / \mathrm{HH}$ & $<26$ & 38.5 & \\
\hline Pinus halepensis Mill. & $\begin{array}{l}\text { Israel } \\
\text { (Negev) }\end{array}$ & 8 & Daily income collecting season & \$23-\$64/day & $<27$ & $\begin{array}{l}\text { Month } \\
\text { here } \\
\text { less }\end{array}$ & $\begin{array}{l}\text { harvest } 3 \text { weeks, so } 15 \\
\text { days }\end{array}$ \\
\hline Pinus oocarpa Schiede & Honduras & 5 & $\begin{array}{l}\text { Daily income in collecting season } \\
4 \text { days/mo. }\end{array}$ & 90 lps. (\$5) & any & & $\begin{array}{l}\text { year-round, less in July- } \\
\text { February; so } 173 \text { days }\end{array}$ \\
\hline Piper betel Blanco & Bangladesh & 3 & $\begin{array}{l}\mathrm{HH} \text { yearly income sales/yr. (8 HH } \\
\text { in village) }\end{array}$ & $\begin{array}{l}33652 \text { TK betel leaf, } \\
2358 \text { TK Betel nut }\end{array}$ & $<127$ & & \\
\hline Tamarindus indica L. & Benin & 2 & $\begin{array}{l}6 \text { months per capita income use } \\
\text { value (woman) }\end{array}$ & $5021 \mathrm{XOH}$ & $<10$ & & $\begin{array}{l}\text { dry season } 6 \text { months; } 132 \\
\text { days }\end{array}$ \\
\hline Tricholoma matsutake Sing. & China & 8 & $\begin{array}{l}\text { Household sales income per year } \\
\text { Revenue/hh/year }\end{array}$ & $\begin{array}{l}2200 \text { CNY mushrooms; } \\
350 \text { CNY medicinal } \\
\text { plants } \\
\begin{array}{l}19583-22166 \text { Y; } \$ 2448- \\
\$ 2760\end{array}\end{array}$ & $\begin{array}{l}<83 \\
<69\end{array}$ & $\begin{array}{l}78 \\
757\end{array}$ & $\begin{array}{l}44 \text { days in season } \\
40 \text { days }\end{array}$ \\
\hline Bryophyte & China & 8 & $\begin{array}{l}\text { Revenue/hh/ year } \\
\text { income/per capita/yr }\end{array}$ & $\begin{array}{l}350 \text { CNY medicinals } \\
1569 \text { Yuan }\end{array}$ & $\begin{array}{l}<10 \\
<208\end{array}$ & 12.5 & 40 days \\
\hline Herb & $\begin{array}{l}\text { India } \\
\text { Philippines } \\
\text { Vietnam }\end{array}$ & $\begin{array}{l}8 \\
8 \\
2,7\end{array}$ & $\begin{array}{l}\text { Projected yearly income per capita } \\
\text { HH consumption/use value/year } \\
\text { Cash income/ per capita/yr. }\end{array}$ & $\begin{array}{l}\text { 134-4955 Rps. } \$ 4-\$ 147 \\
37,648 \text { pesos } \\
52,000 \text { VND }\end{array}$ & $\begin{array}{l}<133 \\
<223 \\
<6.5\end{array}$ & Sep-36 & \\
\hline
\end{tabular}


Stanley et al. 2012. Is Non-Timber Forest Product Harvest Sustainable in the Less Developed World? A Systematic Review of the Recent Economic and Ecological Literature. Ethnobio Conserv 1:9

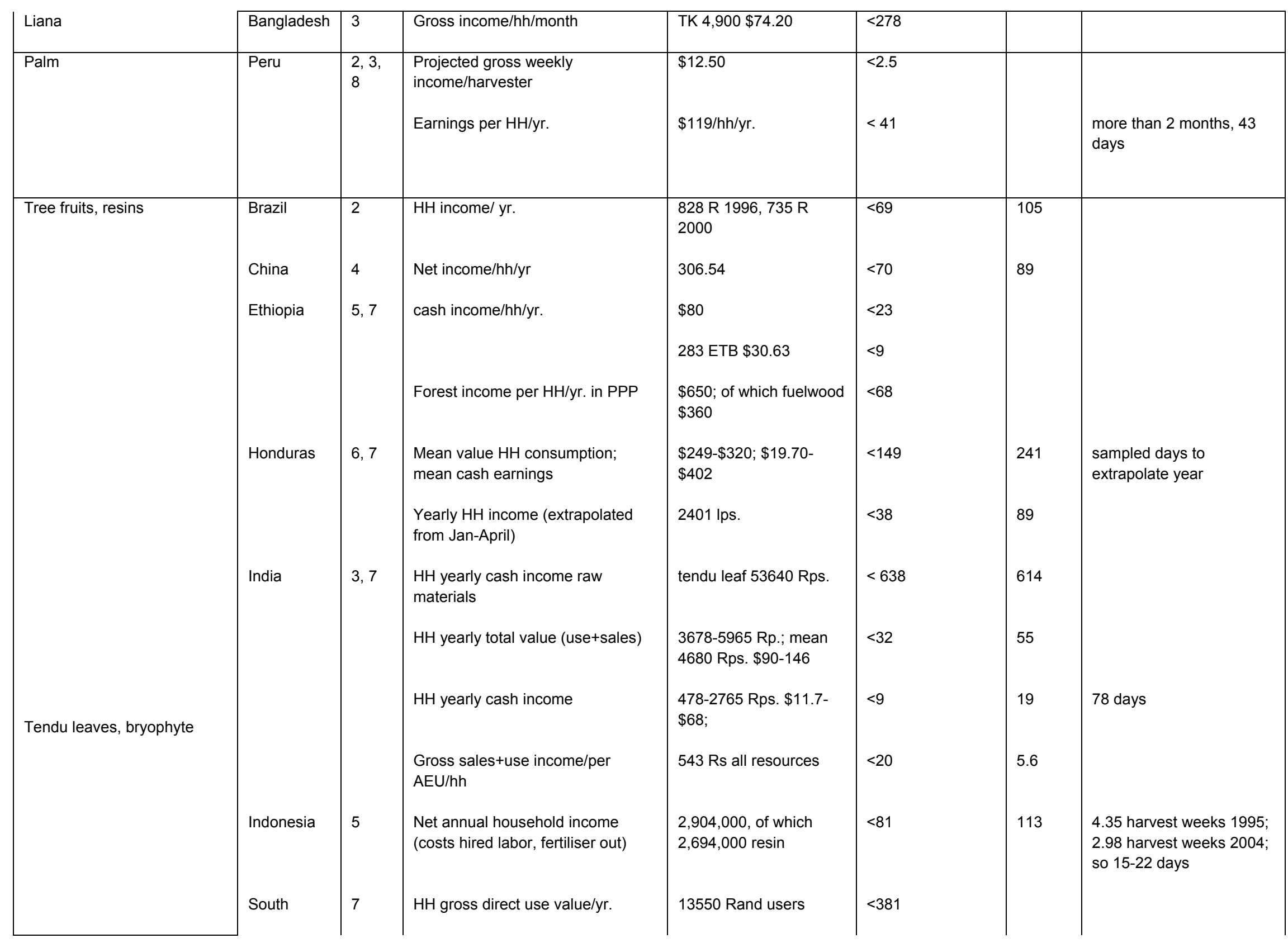


Stanley et al. 2012. Is Non-Timber Forest Product Harvest Sustainable in the Less Developed World? A Systematic Review of the Recent Economic and Ecological Literature. Ethnobio Conserv 1:9

\begin{tabular}{|c|c|c|c|c|c|c|c|}
\hline Resin & $\begin{array}{l}\text { Africa } \\
\text { Zimbabwe }\end{array}$ & 7 & $\begin{array}{l}\text { Fuelwood, woodland products } \\
\text { value/hh/yr substitute value }\end{array}$ & $\begin{array}{l}\$ 45-\$ 74 \text { net; } \$ 180-\$ 296 \\
\text { gross }\end{array}$ & $<22$ & 53 & $\begin{array}{l}\text { seasonal } 3 \text { months, } 65 \\
\text { days }\end{array}$ \\
\hline Palm, Herb & Bolivia & 3 & Consumption value/HH/yr. & $\$ 268$ plants & & 80 & \\
\hline $\begin{array}{l}\text { Tree, Bryophyte } \\
\text { Rubber }\end{array}$ & China & 5,8 & Revenue/hh/year & $\begin{array}{l}\$ 150-\$ 649 ; \text { of which } \\
\text { rubber } \$ 408 ; \text { NTFP } \\
\$ 46.50\end{array}$ & $<118$ & $\begin{array}{l}119 \\
\text { rubber; } \\
13.5 \\
\text { NTFP }\end{array}$ & $\begin{array}{l}12 \mathrm{hrs} . / \text { person/wk. March; } \\
6.3 \mathrm{hrs} . / \text { person/wk April- } \\
\text { June; about } 16.5 \text { days }\end{array}$ \\
\hline $\begin{array}{l}\text { Tree, Herb } \\
\text { Resin }\end{array}$ & $\begin{array}{l}\text { India } \\
\text { Malawi } \\
\text { South } \\
\text { Africa } \\
\text { Sri Lanka } \\
\text { Vietnam }\end{array}$ & $\begin{array}{l} \\
3 \\
2,7\end{array}$ & $\begin{array}{l}\text { Income/day/collector } \\
\text { Annual per capita income } \\
\text { (commercial and subsistence } \\
\text { values) } \\
\text { HH revenue/yr. } \\
\text { Total value (income+use)/hh/year } \\
\text { HH gross direct use value/yr. } \\
\text { HH gross direct use value/year } \\
\text { HH gross direct use value/yr. } \\
\text { HH value/yr. for cash sales, OC } \\
\text { time, substitutes } \\
\text { Consumption value/hh/year }\end{array}$ & $\begin{array}{l}\begin{array}{l}\text { \$3.15/day all } \\
\text { households; } \$ 21.26 \\
\text { damar }\end{array} \\
1001 \text { Rps. \$28 } \\
\text { 1233-2445 Rs. Dry vs. } \\
\text { evergreen species } \\
8256 \text { MK } \\
\text { 3941 Rand users total;; } \\
\text { sherbs } 111 \text { R users } \\
\text { \$707 users } \\
3959 \text { Rand; } \$ 559 \\
2363 \text { Rps. NTFP } \$ 22 \\
58,000,000 \text { VND } \$ 3,867\end{array}$ & $\begin{array}{l}<4.5 \\
<43 \\
<6 \\
<26 \\
<131 \\
<138 \\
<745 \\
<6.5 \\
<1530\end{array}$ & $\begin{array}{l}13.5 \\
28 \\
336 \\
707 \\
8\end{array}$ & $\begin{array}{l}\text { work } 1528 \mathrm{hrs} / \mathrm{yr} . \\
\text { gathering, about } 191 \text { days } \\
90-100 \text { days }\end{array}$ \\
\hline Tree, Herb, Bryophyte & $\begin{array}{l}\text { Sri Lanka } \\
\text { Vietnam }\end{array}$ & $\begin{array}{l}2 \\
3,7,7\end{array}$ & $\begin{array}{l}\text { HH gross direct/income value/yr. } \\
\text { cash sales, OC time, subs } \\
\text { Total cash and environmental }\end{array}$ & $\begin{array}{l}2402 \text { Rps. NTFPs; } \\
4252.5 \text { Rps. Fuelwood } \\
660,125 \text { VND }\end{array}$ & $\begin{array}{l}<8.5 \\
<40\end{array}$ & 9 & \\
\hline
\end{tabular}


Stanley et al. 2012. Is Non-Timber Forest Product Harvest Sustainable in the Less Developed World? A Systematic Review of the Recent Economic and Ecological Literature. Ethnobio Conserv 1:9

\begin{tabular}{|c|c|c|c|c|c|c|c|}
\hline & & 8 & $\begin{array}{l}\text { subsistence income/hh/yr. } \\
\text { Income/hh/year }\end{array}$ & $7,715,000$ VND & $<196$ & & \\
\hline Tree, Palm & Peru & $\begin{array}{l}2,3 \\
8\end{array}$ & $\begin{array}{l}\text { net Value (use, sale) } \\
\text { gathering/hh/yr. after materials }\end{array}$ & $\$ 668$ & $<127$ & & 18-69 days \\
\hline Tree, Palm, Herb & Malaysia & 2,8 & $\begin{array}{l}\text { Median monthly income (cash and } \\
\text { use)/hh } \\
\text { Value of extraction/hh/year } \\
\text { (indirect opportunity cost method) }\end{array}$ & $\begin{array}{l}\text { 65-72 RM ( less without } \\
\text { animals) } \\
\$ 1,049 / \mathrm{hh} / \text { year PPPUS } \\
\$ 2,455\end{array}$ & $\begin{array}{l}<44 \\
<277\end{array}$ & 101 & $\begin{array}{l}60 \text { days/yr as } 20 \% \text { of } 300 \\
\text { days/yr. work }\end{array}$ \\
\hline $\begin{array}{l}\text { Tree, Shrub } \\
\text { Blackberry } \\
\text { Tila }\end{array}$ & Mexico & 2 & $\begin{array}{l}\text { Value of cash income/person/year } \\
\text { @ 2-8 days/yr. }\end{array}$ & $\begin{array}{l}\text { N\$702 P blackberry, } \\
\text { N\$357 Tila }\end{array}$ & & 8 & \\
\hline
\end{tabular}

Legend: *Parts Harvested summarized by Identifier and Country - 1: Flower, inflorescence; 2: Fruit, seed, nut; 3: Leaves, fronds, foliage; 4: Root, tuber, bulb, corms; 5: Resin, pulp, woody portion**; 6: Bark; 7: Branch; 8: Whole plant, heart, stem, meristem. **Woody refers to NTFPs derived from modified, decomposed, or pulpy woody parts such as Gaharu. (p) part of same study.

Note: Bryophyte category also includes mushrooms, lichens, and all other forms

Sources: Ambrose-Oji 2003; Arora 2008; Arun 2004; Bista and Webb 2006; Campbell et al. 1997; Chaudry et al. 2008; Chaudry et al, 2008; Coomes et al.2004; Delang 2006; Dovie et al. 2002; Escobar and Aldana 2003; Ezebilo and Mattson 2010; Fandohan et al. 2010; Fu et al.2009; Fu et al.2009b; Godoy et al.2002; Gram 2001; Gram et al.2001; Gubbi and MacMillan 2008; He et al. 2009; Hedge and Enters 2000; Howell et al. 2010; Huber et al. 2010; Illukpitiya and Yanagida 2008; Illukpitiya and Yanagida 2010; Jensen and Melby 2010; Kamanga et al., 2008; Kim et al. 2008; Kronborg et al. 2008; Kusters et al. 2008; Kvist et al., 2001; Lemenih 2003; Lopez-Feldman et al. 2007; Mahapatra et al.2005; Mamo et al. 2007; Maraseni et al. 2008; Marshall and Newton 2003; Mcelwee 2008; McSweeney 2002; Montoya et al. 2008; Murthy et al. 2005; Nahuelhaul et al. 2008; Narain et al. 2007; Narendran et al. 2001; Ngueyn 2006; Nygren et al. 2006; Pabuayon 2004; Paoli et al. 2001; Pyhala et al. 2006; Quang and Anh 2006; Quang and Norik 2008; Rahman et al.,2009; Rai and Uhl 2004; Reyes-Garcia et al. 2006; Riadh 2007; Rueff et al.2008; Shackleton et al. 2002a; Shackleton et al. 2002b; Shackleton et al. 2007b; Shone and Caviglia-Harris 2006; Shylajan and Mythili 2003; Stoian 2005; Svarrer and Olsen 2005; Twine et al. 2003; Weinstein and Moegenburg 2004; Weinstein and Moegenburg 2004; Wollenberg 2001; Yang et al. 2009. 